\title{
Identification of driving factors of land, water, energy and food (LWEF) nexus resources: $A$ perspective of environmental degradation in Gidabo Watershed, Southern Ethiopia
}

\author{
Zinabu Wolde ( $\square$ sos.zine04@gmail.com ) \\ Nanjing Agricultural University \\ Wu Wei \\ Nanjing Agricultural University - Weigang Campus: Nanjing Agricultural University \\ Haile Ketema \\ Nanjing Agricultural Technical College: Jinling Institute of Technology \\ Eshetu Yirsaw \\ Dilla College: Dilla University \\ Habtamu Temesegn \\ Dilla College: Dilla University
}

\section{Research Article}

Keywords: land-water-energy-food nexus, driving factor, indicators, degradation, path coefficient

Posted Date: April 5th, 2021

DOI: https://doi.org/10.21203/rs.3.rs-234895/v1

License: (a) (i) This work is licensed under a Creative Commons Attribution 4.0 International License.

Read Full License 


\title{
Identification of driving factors of land, water, energy and food (LWEF) nexus resources: A perspective of environmental degradation in Gidabo Watershed, Southern Ethiopia
}

\author{
Zinabu Wolde ${ }^{1,3}$, Wu Wei ${ }^{1,2^{*}}$, Haile Ketema ${ }^{1,3}$, Eshetu Yirsaw ${ }^{3}$ and Habtamu Temesegn ${ }^{3}$ \\ ${ }^{1}$ College of Land Management, Nanjing Agricultural University, Nanjing 210095, China \\ ${ }^{2}$ Joint Engineering Research Center for Rural Land Resources Use and Consolidation, \\ Nanjing 210095, China \\ ${ }^{3}$ Dilla University, College of Agriculture and Natural Resources, Dilla, Ethiopia \\ *Corresponding author: sos.zine04@gmail.com
}

\begin{abstract}
In Ethiopia, land, water, energy, and food (LWEF) nexus resources are under pressure, due to population growth, urbanization and economic growth. However, the impact of these factors are less explored at local scale level. As a result, securing nexus resource is becoming a serious challenge. This necessitates identification of driving factors for sustainable utilization of scarce LWEF nexus resources. Our study provides a systemic look at the driving factor indicator that induces nexus resource degradation. We use Analytical Hierarchical Process (AHP) to develop indicator weight and Path Analysis Model(PAM) to quantitatively estimates the effect of driving factor indicators on LWEF nexus resources. The result indicates that, social (48\%), economic (19\%) and policy and institutional changes (14\%) are the major nexus resource driving factor indicators. The path analysis result indicates that from social driving factor indicators population growth, and consumption patterns have significant direct effect on LWEF nexus with the path coefficient of 0.15 and 0.089 , respectively. Similarly, the potential of LWEF nexus resources is also influenced by the institutional and policy change drivers such as outdated legislation and poor institutional structure with the path coefficient of 0.46 and 0.39 , respectively. This implies that population growth and consumption pattern are the leading social drivers, while outdated legislation and poor institutional structure are institutional and policies change drivers which have potential impact on LWEF nexus resources degradation. Similarly, other driving factor indicators (environmental, economic and technological) also affect nexus resources with varying amount. The finding of our study show the benefits of managing identified driving factors for the protection of LWEF nexus resources, which have close link with human health and the environment. In order to alleviate the adverse effects of driving factors, all stake holders need to show permanent individual and collective commitment. Furthermore, we underline the necessity of applying LWEF nexus approaches to manage these drivers, and optimize environmental and social outcomes.
\end{abstract}

Keywords: land-water-energy-food nexus; driving factor; indicators; degradation; path coefficient

\section{Introductions}

There has been a growing demand of land, water, energy and food (LWEF) nexus resources in the past half-century due to increasing population growth, economy growth and urbanization (Al-Saidi and Elagib, 2017; Ringler et al., 2013). Today, more than one a billion people are facing shortage of land, water, energy and food due to anthropogenic factors. However, there are also natural factors (i.e., climate, topographic feature and resource 
distribution) that substantially contribute for degradation of nexus resources (Imasiku and Ntagwirumugara, 2020). This diminishes the capacity of nexus resources that perform essential function and services in ecosystem (Abel et al., 2020; Bakhshianlamouki et al., 2020).

The concept of nexus has gained increasing attention in the research and policy making communities (Ding et al., 2020; Li et al., 2020; van Gevelt, 2020). However, there was inadequacy to identify factors that affect pool of LWEF nexus resources which necessitates comprehensive study and critical reflection on existing nexus resources drivers (Ringler et al., 2013; van Gevelt, 2020; Zare et al., 2020). Identifying driving factors of land, water, energy and food are critical to provide useful information for improving the sustainable utilization of nexus resources (Al-Saidi and Elagib, 2017; Ali et al., 2019; Imasiku and Ntagwirumugara, 2020).

Currently studies focusing on synergies between LWEF nexus resources and individual nexus resources driver from global, national and regional scale are being conducted (Ringler et al., 2013; Terrapon-Pfaff et al., 2018; Weitz et al., 2014) and also on the individual nexus resources driver's from global, national and regional scale (Laspidou et al., 2019; Mabhaudhi et al., 2019; Nie et al., 2019; Ringler et al., 2013). However, the complex relationship existing among these nexus resources is making it difficult to easily understand the synergies between them and identify their drivers. This complicates the management and leads to nexus resources degradation (Wiegleb and Bruns, 2018). Therefore, understanding nexus resource drivers play essential roles for sustainable nexus resource management. However, the driving factors are not distributed uniformly across the region and varies with the patterns of geography, climate, economic development, social and political integration and transformation of the landscape (Duan and Chen, 2020; Wang and Zhao, 2018). This necessitates site specific action in terms of management which can be achieved by identifying resources driving factor indicators. These indicators are perceived by the public and used as simplified and aggregated forms to present information pertaining to a certain region (Collomb et al., 2010; Dale and Beyeler, 2001; Fraser et al., 2006).

Results of various studies demonstrated that demand for productive land, water, energy and food is driven by common driving factors such as rapid population growth, urbanization and climate change (Dibaba et al., 2020). However, there are many other driving factor indicators affecting nexus resources especially at local level. Eventhogh the nexus resource driving factor indicators are varying on the basis of small geographical units, while studies conducted so far were focused at large scale (Ding et al., 2020). Hence the existing studies have not 
developed the nexus resources driver indicators from local level perspective, for which our study area is not exceptional. In the study landscape the existence of LWEF nexus and the prevalence of their drivers appear to be high and vary throughout the area as a result of multifaceted of land-uses, water, energy access, and food insecurity that had been causing the nexus resource degradation (Dibaba et al., 2020). Therefore, this study attempts to select nexus resource drivers in relation to the prevailing conditions in the study area and finally use path coefficient analysis to model the causal relationship between LWEF nexus and drivers. With this, the study intended to (i) identify LWEF nexus resources driving factor indicators that affect nexus resource (ii) explore the extent and trends of a driver on four nexus resources (iii) identify the direct and indirect impact of driving factors on LWEF nexus resources.

\section{Material and Methods}

\subsection{Study area}

Gidabo watershed was chosen as the subject of this study to explore the relationship between land, water, energy and food nexus and its driving factors. This watershed is part of central rift valley of Ethiopia, where agricultural expansion and built up land is expanding rapidly (Wolde et al., 2020). The expansion of agriculture and built up in this watershed resulted in population growth and increased demand of productive land and water, energy, and food nexus resources.

In central Ethiopia, the main Ethiopian Rift, divides the Ethiopian highlands into northeastern and southwestern halves. This rift includes the Ethiopian Rift Valley lakes which occupy the floor of the rift valley, with different sub-watersheds. The Gidabo watershed is located from $6^{0} 9^{\prime} 4$ ' ' to $6^{0} 56^{\prime} 4^{\prime \prime}$ 'N latitudes and $37^{0} 55^{\prime}$ to $38^{0} 35^{\prime}$ 'E longitude (figure 1 ). It has a peak of $3213 \mathrm{~m}$ a.s.l. and the lowest altitude is about $1171 \mathrm{~m}$.a.s.l. 


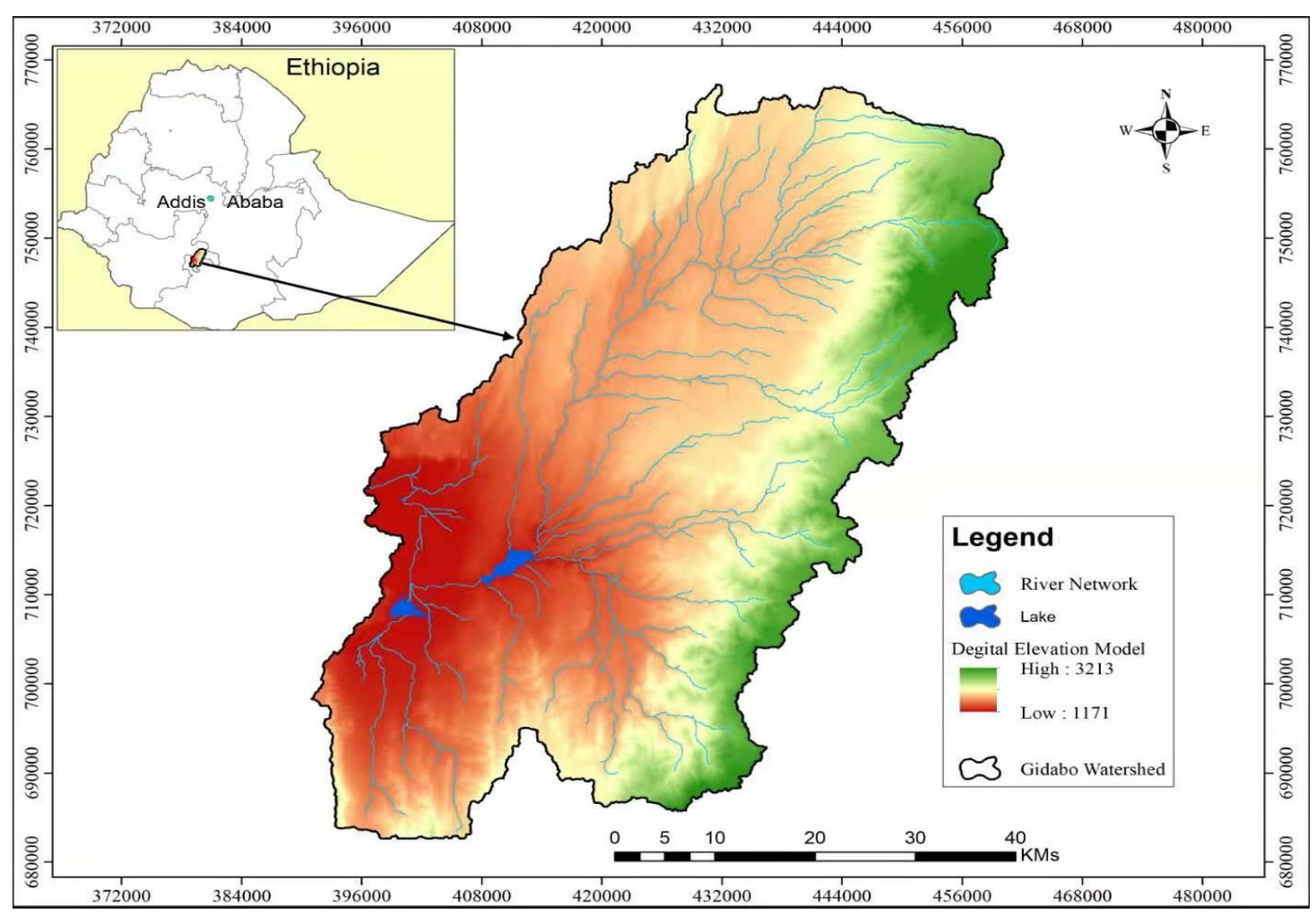

Figure 1: Map of the case study area.

This watershed is bordered by the catchment of Lake Hawassa to the North, River Bilate to the West, river Galana to the South and Genale-Dawa River basin to the East, which considered as a potential livelihoods sources for Southern Ethiopia. The populations are settled more towards the eastern highland and the population density decreases towards the eastern low lands. There is more population around the eastern highlands and it reduces as one goes down to eastern lowlands. However, the population of the watershed has been growing alarmingly in the last three decades and currently it is more than 1.5 million. The upper part is more populated (>500 inhabitants per square kilometers), and has immense impact on potential nexus resources. The livelihoods of the local community in the study area primarily depend on mixed farming and livestock rearing(Ketema et al., 2020), which are sensitive to land, water, energy and food. Therefore, due to the current nexus resource degradation by various driving factors, most farmers in the watershed live with lowest access to electricity, clean water and modern infrastructure and they are vulnerable to frequent food insecurity.

\subsection{Data sources and Techniques}

This study focuses on driving factors indicator of LWEF nexus, which were identified from varied literature sources and deep survey in the history of nexus resources status. Additionally, data were collected from key informants and local community using combination of 
structured interviews. Secondary data sources were also used for validation of LWEF nexus indicators. Identification of driving factor indicators helps to have common understanding and to easily categorize which LWEF nexus resources directly or indirectly affected by driver. The survey was conducted within four-month period from July 2019 to October 2019, following two approaches. First, expert interviews and focus group discussion $(\mathrm{N}=50)$ were conducted with respondents from natural resources, agriculture, water and energy sectors in order to characterize driving factors (Table 1). Second, questionnaires were distributed to a total of 434 households, in order to find out how local community perceives identified driving factor indicators. To perform this, the respondents were asked to rank each predefined indicator impact on LWEF nexus from 0 to 4 ranking ( $4=$ extreme, $3=$ high, $2=$ medium, $1=$ low, $0=$ negligible).

\subsection{Selection of LWEF nexus resources drivers}

According to Taherzadeh and Caro (2019), driving factors are defined as driving forces consisting of different components that can affect societal change or natural system. Understanding driving factors helps in identifying status, development and management of LWEF nexus resource to ensure equity and sustainability(Terrapon-Pfaff et al., 2018). The driving factor indicator is a variable that describes the status of the nexus resources and its impact on the availability, and distribution trends of nexus resources. In nexus resources management, a single indicator cannot efficiently describe a complex process that affects land, water, energy and food degradation(Spiegelberg et al., 2017). Therefore, indicators are combined to create a composite index to monitor the state of the nexus resources. Sola et al. (2017) stated that environmental indicators may be considered as a simplified form to present information to a certain region. Therefore, in our current study, we consider nexus resources drivers' indicators to clearly understand area specific driving factors (Table 1).

The nexus resources driving factor variables were selected in relation to the objectives and the prevailing conditions in the case study area from relevant literature and discussed further with expert's. Finally, the researchers and expertise from the four sectors were organized in a group, to provide feedback on interim results of the factors affecting nexus resources. Table 1 provides five main and twenty-five sub driving factors indicators and their explanation.

During identification and grouping of indicators, particularly sub-indicators, we tried to reduce overlap and mix up of sub-indicators to reduce multicollinearity of sub-indicators. During our field investigation, the local community choses 47 different driving factor indicators. Following this, a discussion was held among expert from agriculture, water and energy, natural resource and environmental management sectors to score and rank sub- 
indicator and categorize into the main indicators. After careful evaluation, the experts bring identified 25 sub-driving factor indicators.

To verify this result we computed multicollinearity for the entire identified indicators using Variance Inflation Factor (VIF) analysis. The finding of the analysis revealed that 22 indicators had strong correlation with each other and removed from the analysis the final result of the analysis shows that the computed mean VIF is 3.4 which is satisfactory to show there is no multicollinearity. Therefore, finally 25 sub-indicators were identified and categorized into five main driving factor indicators. Besides, we also defined each subindicator in order to reduce data-based multicollinearity, which can be removed using subject-area knowledge and factor in the goal, as reported by(Graham, 2003; Shieh, 2010) 
Table 1. LWEF nexus resource driving factor indicators in the study area.

\begin{tabular}{|c|c|c|c|c|c|}
\hline S/No & $\begin{array}{l}\text { Main driver } \\
\text { indicators }\end{array}$ & $\begin{array}{l}\text { Sub-driver } \\
\text { indicators }\end{array}$ & Code & Description & Literature \\
\hline \multirow[t]{6}{*}{1} & \multirow[t]{6}{*}{ Social } & Population growth & SC1 & $\begin{array}{l}\text { A growing population } \\
\text { will increase the use of } \\
\text { natural resources. }\end{array}$ & \multirow{6}{*}{$\begin{array}{l}\text { (Barbier and } \\
\text { Hochard, 2018; } \\
\text { Helmy, 2020; } \\
\text { Imasiku and } \\
\text { Ntagwirumugara, } \\
\text { 2020; Mohtar and } \\
\text { Lawford, 2016; } \\
\text { Pimentel et al., } \\
\text { 2010; Rijal et al., } \\
\text { 2020; Wolde et al., } \\
\text { 2020) }\end{array}$} \\
\hline & & Poverty & SC2 & $\begin{array}{l}\text { Poverty is increasingly } \\
\text { recognized as an important } \\
\text { driver of forest which affect } \\
\text { WEF system. }\end{array}$ & \\
\hline & & $\begin{array}{l}\text { Lack of alternative } \\
\text { livelihoods }\end{array}$ & SC3 & $\begin{array}{l}\text { Lack of alternative } \\
\text { livelihoods leads to little } \\
\text { stake in the health and } \\
\text { productivity of natural } \\
\text { resources. }\end{array}$ & \\
\hline & & $\begin{array}{l}\text { Consumption } \\
\text { patterns }\end{array}$ & SC4 & $\begin{array}{l}\text { Consumption patterns } \\
\text { fairly convincingly } \\
\text { explains the dynamics of } \\
\text { poor approach to natural } \\
\text { resources and their } \\
\text { resource use behavior. }\end{array}$ & \\
\hline & & $\begin{array}{l}\text { Community } \\
\text { awareness }\end{array}$ & SC5 & $\begin{array}{l}\text { Ignorance of local } \\
\text { community knowledge is } \\
\text { becoming both limitation of } \\
\text { their environmental } \\
\text { resource and consequence } \\
\text { of their using practices. }\end{array}$ & \\
\hline & & $\begin{array}{l}\text { Lack of Public } \\
\text { involvement }\end{array}$ & SC6 & $\begin{array}{l}\text { Evolving technical and } \\
\text { institutional measure to } \\
\text { prevent over-extractive } \\
\text { resource use. }\end{array}$ & \\
\hline \multirow[t]{2}{*}{2} & \multirow[t]{2}{*}{ Economic } & $\begin{array}{l}\text { Increasing income } \\
\text { variability }\end{array}$ & EC1 & $\begin{array}{l}\text { Natural resources provide } \\
\text { important services to both } \\
\text { local on-site and off-site } \\
\text { beneficiary, while most off- } \\
\text { site beneficiary are "free } \\
\text { rider", this related with } \\
\text { income variation. }\end{array}$ & \multirow[t]{2}{*}{$\begin{array}{lr}\text { Dogan et al., } \\
\text { 2020; Karlberg et } \\
\text { al., 2015; Ringler } \\
\text { et al., 2013; } \\
\text { Tanner } \quad \text { and } \\
\text { Johnston, 2017; } \\
\text { Terrapon-Pfaff et } \\
\text { al., 2018) }\end{array}$} \\
\hline & & Low capital & EC2 & $\begin{array}{l}\text { Lack of allocation of } \\
\text { sufficient capital } \\
\text { investment for resource } \\
\text { rehabilitation and control } \\
\text { leads to degradation, since } \\
\text { capital budget provides an } \\
\text { important tool for the } \\
\text { control and evaluation of } \\
\text { resources. }\end{array}$ & \\
\hline
\end{tabular}




\begin{tabular}{|c|c|c|c|c|c|}
\hline & & $\begin{array}{l}\text { Increasing WEF } \\
\text { prices }\end{array}$ & EC3 & $\begin{array}{l}\text { Implication of raising } \\
\text { energy prices linked supply } \\
\text { of firewood and charcoal, } \\
\text { this induces pressure on } \\
\text { land resources. }\end{array}$ & \multirow{7}{*}{$\begin{array}{l}\text { (deLlano-Paz et } \\
\text { al., 2019; Granit et } \\
\text { al., 2012; Kurian, } \\
\text { 2017; Mabhaudhi } \\
\text { et al., 2019; } \\
\text { Mendoza et al., } \\
\text { 2020; Pahl-Wostl, } \\
\text { 2019; Sušnik et al., } \\
\text { 2018; Trock, 1969) }\end{array}$} \\
\hline & & $\begin{array}{l}\text { Increasing land } \\
\text { value }\end{array}$ & EC4 & $\begin{array}{l}\text { In recent decades, alarming } \\
\text { land value leads to strong } \\
\text { land speculation and } \\
\text { grabbing, in which } \\
\text { expansion of small, large } \\
\text { and unplanned industries } \\
\text { affect nexus resources. }\end{array}$ & \\
\hline & & $\begin{array}{l}\text { Inadequate } \\
\text { financial resources }\end{array}$ & EC5 & $\begin{array}{l}\text { Low funding level to } \\
\text { restore degraded LWEF } \\
\text { nexus resources both from } \\
\text { government and NGO's } \\
\text { results on unwise and open } \\
\text { use of nexus resources. }\end{array}$ & \\
\hline \multirow[t]{4}{*}{3} & \multirow[t]{4}{*}{$\begin{array}{l}\text { Institutional } \\
\text { and policy } \\
\text { change }\end{array}$} & $\begin{array}{l}\text { Outdated } \\
\text { legislation }\end{array}$ & IP1 & 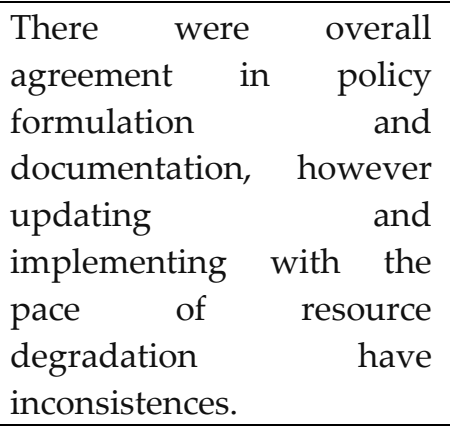 & \\
\hline & & $\begin{array}{l}\text { Inadequate } \\
\text { financial capital }\end{array}$ & IP2 & $\begin{array}{l}\text { Inadequate financial capital } \\
\text { is characterized by high } \\
\text { quality LWEF nexus } \\
\text { institution which leads to } \\
\text { higher rate of innovation } \\
\text { and interlinked business } \\
\text { formulation. }\end{array}$ & \\
\hline & & $\begin{array}{l}\text { Poor institutional } \\
\text { structure }\end{array}$ & IP3 & $\begin{array}{l}\text { LWEF resources can } \\
\text { potentially contribute to } \\
\text { development outcomes, } \\
\text { but nowadays those } \\
\text { resources are plagued with } \\
\text { unsustainability, poor } \\
\text { governance, corruption } \\
\text { and conflict of interest } \\
\text { which lead to degradation. }\end{array}$ & \\
\hline & & $\begin{array}{l}\text { Poor stakeholder } \\
\text { network }\end{array}$ & $\mathrm{IP} 4$ & $\begin{array}{l}\text { Stakeholder analysis can be } \\
\text { used to avoid inflaming } \\
\text { conflicts among land, } \\
\text { water, energy and food } \\
\text { sectors, and ensure that the } \\
\text { marginalization of certain } \\
\text { groups is not reinforced, }\end{array}$ & \\
\hline
\end{tabular}




\begin{tabular}{|c|c|c|c|c|c|}
\hline & & & & $\begin{array}{l}\text { and fairly represent diverse } \\
\text { interest. }\end{array}$ & \\
\hline \multirow[t]{5}{*}{4} & \multirow[t]{5}{*}{ Environmental } & $\begin{array}{l}\text { Fuel wood } \\
\text { dependence }\end{array}$ & EN1 & $\begin{array}{l}\text { As populations is } \\
\text { increasing from time to } \\
\text { time, there would be a } \\
\text { massive wood fuel } \\
\text { shortage and that an } \\
\text { increasingly desperate } \\
\text { population would move } \\
\text { into untouched forests, } \\
\text { causing massive } \\
\text { deforestation. }\end{array}$ & \multirow[t]{5}{*}{$\begin{array}{l}\text { (Amenu, 2017; } \\
\text { Costa et al., 2019; } \\
\text { Estoque et al., } \\
\text { 2019; Hathaway, } \\
\text { 2008; Liu, 2016; } \\
\text { Nie et al., 2019; } \\
\text { Tanner and } \\
\text { Johnston, 2017; } \\
\text { Vivoda, 2017) }\end{array}$} \\
\hline & & $\begin{array}{l}\text { Charcoal } \\
\text { production }\end{array}$ & EN2 & $\begin{array}{l}\text { Charcoal production has } \\
\text { greater environmental cost. } \\
\text { It is made by burning large } \\
\text { logs in kilns or in mounds } \\
\text { of earth to create low- } \\
\text { oxygen environment, this } \\
\text { leads land degradation } \\
\text { which affect water, energy } \\
\text { and food. }\end{array}$ & \\
\hline & & $\begin{array}{l}\text { Agricultural } \\
\text { expansion }\end{array}$ & EN3 & $\begin{array}{l}\text { Agricultural } \\
\text { developments are an } \\
\text { important driving force } \\
\text { behind developments } \\
\text { and the organization of } \\
\text { society as a whole, which } \\
\text { often results in intensive } \\
\text { dynamic land-use } \\
\text { changes. }\end{array}$ & \\
\hline & & Land use change & EN4 & $\begin{array}{l}\text { Land use change } \\
\text { encompasses different } \\
\text { types of land use expansion } \\
\text { in the expense of LWEF. }\end{array}$ & \\
\hline & & Climate change & EN5 & $\begin{array}{l}\text { Climate change creates } \\
\text { critical challenges with } \\
\text { increasing temperature, } \\
\text { agro-ecological change, } \\
\text { and changing precipitation } \\
\text { for water, energy, and food, } \\
\text { as well as ecosystem } \\
\text { processes. }\end{array}$ & \\
\hline
\end{tabular}




\begin{tabular}{|c|c|c|c|c|c|}
\hline & & $\begin{array}{l}\text { Industrial } \\
\text { expansion }\end{array}$ & EN6 & $\begin{array}{l}\text { Industrial expansion poses } \\
\text { serious challenges in the } \\
\text { use of land, water and other } \\
\text { NRs. }\end{array}$ & \\
\hline \multirow[t]{4}{*}{5} & \multirow[t]{4}{*}{ Technology } & $\begin{array}{l}\text { Lack of input } \\
\text { supply }\end{array}$ & TC1 & $\begin{array}{l}\text { Technological input supply } \\
\text { increase productivity in } \\
\text { agriculture, efficient water and } \\
\text { land use }\end{array}$ & \multirow{4}{*}{$\begin{array}{l}\text { (Chang et al., } \\
\text { 2016; Chen et al., } \\
\text { 2018; Delucchi, } \\
\text { 2010; Gulati et al., } \\
\text { 2013; Lawford, } \\
\text { 2019; Lee et al., } \\
\text { 2019; Li and Ma, } \\
\text { 2020; Orr et al., } \\
\text { 2012; Rasul, 2016) }\end{array}$} \\
\hline & & $\begin{array}{l}\text { Inadequate } \\
\text { technology } \\
\text { adoption and } \\
\text { implementation }\end{array}$ & TC2 & $\begin{array}{l}\text { In developing nations, } \\
\text { millions lack access to } \\
\text { sanitation services and safe } \\
\text { drinking water, modern } \\
\text { energy sources and } \\
\text { optimized land use. }\end{array}$ & \\
\hline & & $\begin{array}{l}\text { Attitude towards } \\
\text { technology } \\
\text { innovation and } \\
\text { development }\end{array}$ & TC3 & $\begin{array}{l}\text { Lack of proactive attitudes } \\
\text { towards technology } \\
\text { efficiency, adoption and } \\
\text { implementation results on } \\
\text { unwise resource use. }\end{array}$ & \\
\hline & & $\begin{array}{ll}\text { Lack } & \text { of } \\
\text { infrastructure }\end{array}$ & TC4 & $\begin{array}{l}\text { There is growing } \\
\text { momentum to address } \\
\text { traditional and emerging } \\
\text { threats to the LWEF } \\
\text { resources through } \\
\text { innovative technology } \\
\text { infrastructure. }\end{array}$ & \\
\hline
\end{tabular}

\subsection{Analytical Hierarchical Process and Pair wise comparison matrix}

The Analytic Hierarchy Process (AHP) and the Pairwise Comparison Matrix (PCM) were used to normalize indicators and establish the indicators weight from expert's judgment (Thanh and De Smedt, 2012).

The PCM is constructed by using scores that represent expert's judgment to compare and measure the importance of indicators in relation to all other indicators using Saaty scale(Saaty, 2016), in which the relationships are established using a scale ranging from 1 to 9 and their reciprocals using question "How important is two identified indicators to drive nexus resources?". Appendix table 1 indicates the result of pairwise comparison matrix of the LWEF nexus indicator computed using the following formula.

$$
C_{v}=\sum_{\mathrm{i}=1}^{\mathrm{n}} X_{i} K_{i r}
$$

where $C_{v}$ indicates the composite value of indicator, $K_{i r}$ the relative change index of driving factors indicators, $K_{i}$ and $X_{i}$ the weight of indicators. Then through further calculation weighting for criteria and indicators within each criterion was computed, as outlined by (Mabhaudhi et al., 2019). Based on the weight value of driving factor indicators, 
the highest weight is computed for social, economic and institutional and policy change, while lowest weight is computed for environmental and technological driver indicator (Figure 2).

Computing composite weight of driving factor indicator provides a starting point for analysis and used as summary indicators to guide policy makers and other data users (Thanh and De Smedt, 2012). From social driving factors population growth (SC1), poverty (SC2) and lack of public involvement (SC6); and from institutional and policy change inadequate financial capital (IP2) and poor institutional structure(IP3) indicators have strong impact on nexus resources degradation (Appendix Table 1).

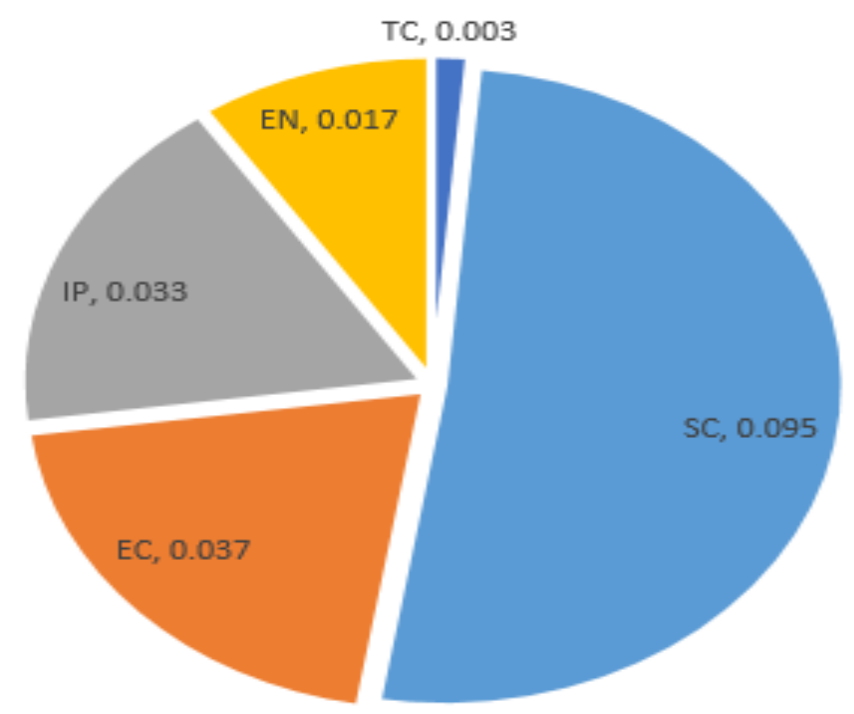

Figure 2. The weight of five main nexus resources driving factor indicators $(E C=$ economic, $I P=$ institutional and policy change, $S C=$ social, $E N=$ environmental and $T C=$ technological drivers)

\subsection{Path coefficient analysis models}

Model has an important role in organizing data and information to guide the identification of indicators needed to attain the required goal (Heuss et al., 2019). Specifically, an indicator based model provides an overview for considering environmental problems. In this study, the path analysis model (PAM) is used to quantitatively analyze the direct and indirect impact of LWEF nexus resources driver.

Path coefficient can be expressed as standardized coefficient which is typically computed either by first standardizing all variables and then computing the path coefficients from the ratios of the standard deviation of the variable. Standardized coefficients allow direct comparisons of the magnitude of effects of two causal variables measured on different scales (Chouksey et al., 2020). A path model may look similar to multiple regression (MaydeuOlivares et al., 2019), where an exogenous variable is analogous to a predictor variable and an endogenous variable is a response; however, the difference is that the endogenous variable 
can be both a predictor and response in a system of equation. An important assumption is that exogenous variables are measured without error, On the other hand, each endogenous variable is assumed to have error.

In path analysis, the correlation co-efficient is partitioned in to direct and indirect effect of independent variable (i.e. driving factors) on the dependent variable (i.e. LWEF nexus resources). In order to estimate direct and indirect effects of the correlated characters, let say $k_{1}, k_{2}$ and $k_{3}$ as driving factor effects on $n$ nexus resources, a set of simultaneous equations is required to be formulated as shown blow;

$$
\begin{gathered}
Y_{n K_{1}}=P_{n K_{1}}+P_{n K_{2}} Y_{k 1 k 2}+P_{n K_{3}} Y_{k 1 k 3} \\
Y_{n K_{2}}=P_{n K_{1}} Y_{k 1 k 2}+P_{n K_{2}}+P_{n K_{3}} Y_{k 2 k 3} \\
Y_{n K_{2}}=P_{n K_{1}} Y_{k 1 k 3}+P_{n K_{3}} Y_{k 2 k 3}+P_{n K_{3}}
\end{gathered}
$$

Where, $P$ denotes path coefficients, $Y$ denotes simple correlation co-efficient. The total correlation between $k_{1}$ and $\mathrm{n}$ is thus partitioned as follows ; $P_{n k_{1}}=$ the direct effect of $k_{1}$

on n, $P_{n k_{2} Y_{k 1 k 2}=}$ the indirect effects of $k 1$ via $k_{2}$ on $n, P_{n k_{3} y_{k 1 k 2}}=$ the indirect effects of $k 1$ via $k_{3}$.

Data processing was done by MS excel 2016 and Stata14 statistical package were used for analysis.

\section{Result and Discussion}

\subsection{Analysis of land, water, energy and food (LWEF) nexus driver factor indicators}

This section introduces main and sub-driving factors that affect one or more of the land, water, energy, and food nexus system. We identified twenty-five sub driving factors, which were categorized under five main driving factors. The results of the analysis indicated that from the five main driving factor indicators, social (48\%), economic (19\%), as well as institutional and policy changes (14\%) are the major driving factors that affect nexus resources (Figure 3). Similarly, the average weight of the main nexus resource driving factor is also computed shows the same trends (Figure 2). The direct and indirect impacts of these driving factors are explained in the subsequent section. 


\section{LWEF nexus driving factors}

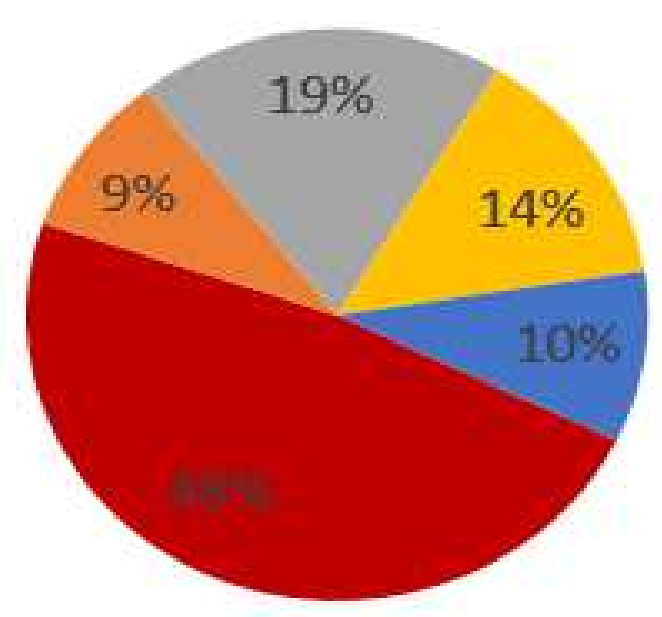

- Social

Environment

Economic

Pol \& Ins change

Technology

Figure 3. Main LWEF nexus resources driving indicator (Pol \& Ins change $=$ policy and

institutional change).

Social life changes, economic sources and institutional and policy change are major driving factors, critical to ensuring land, water, energy and food nexus security. Nowadays, limited understanding towards those drivers results in poor LWEF nexus resource management (van Gevelt, 2020).

\subsubsection{Social drivers}

Six social driving factor indicators were identified based on the related literature (Table 1). Figure 4 indicates the path coefficient analysis result of sub-social driving factor indicators that affect nexus resources; population growth (SC1), poverty (SC2), lack of alternative livelihoods (SC3), consumption patterns (SC4), community awareness (SC5) and lack of public involvement (SC6). The result of path co-efficient analysis revealed that population growth $(p=0.15)$, lack of alternative livelihoods $(p=0.56)$ and lack of public involvement $(p=0.15)$ had a positive direct effect on LWEF nexus resources (Figure 4). Population growth also affects LWEF nexus indirectly $(p=0.005)$ which is mediated by consumption pattern, while poverty had a negative indirect effect $(p=-0.16)$ on LWEF nexus which is mediated by consumption patterns (Figure 4).

The result of path analysis in Figure 4 revealed that community awareness (SC5) had positive direct effect $(p=0.096)$ on LWEF nexus degradation in the study area. This implies lack of community awareness in nexus resource management disrupts the planning and execution of 
nexus resources management. Since, it is important for the success and failure of resource management.

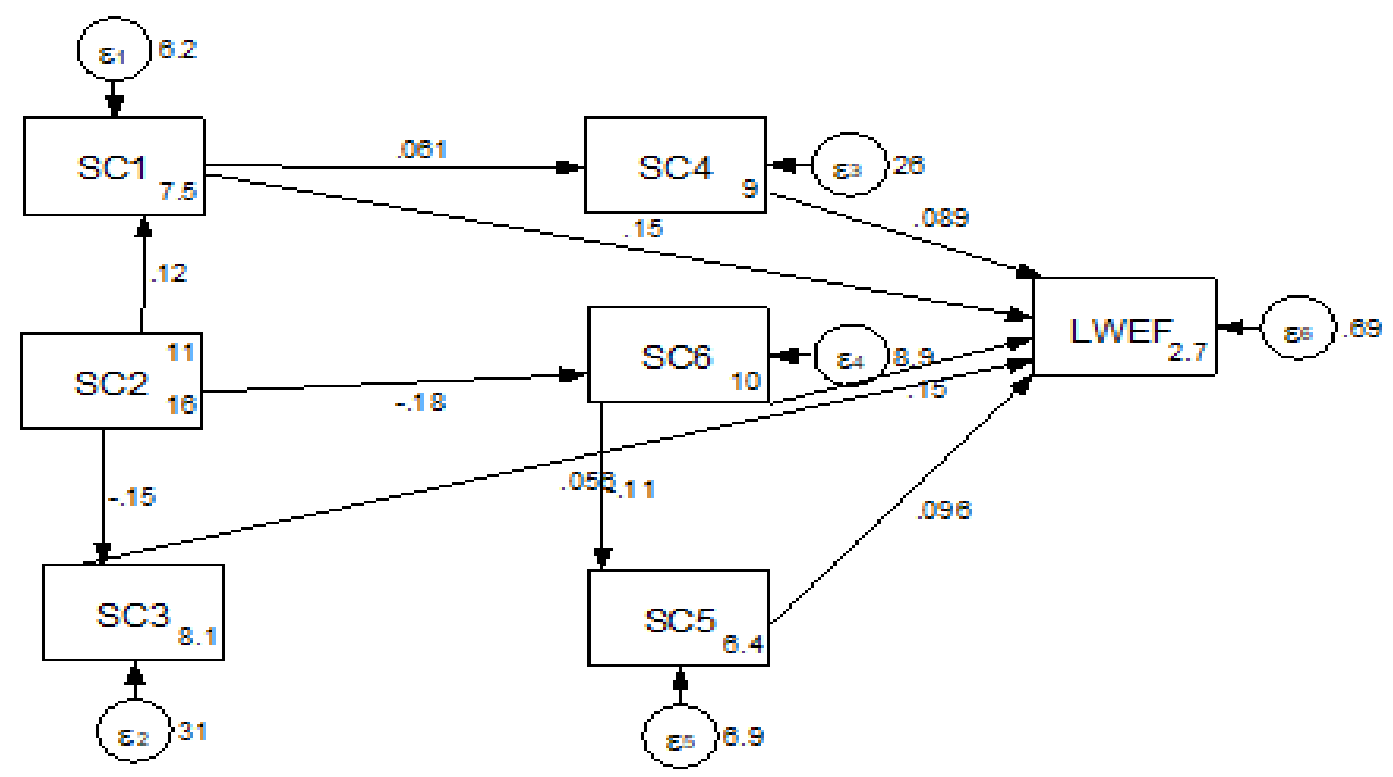

Figure 4. The social driving factor indicator ( $S C 1=$ population growth, $S C 2=$ poverty, $S C 3=$ lack of alternative livelihoods, $S C 4=$ consumption patterns, $S C 5=$ community awareness, and $S C 6=$ lack of public involvement)

The demographic development and characteristics in the study area has implication for high demand on the existing patterns of land, water, energy and food availability and strongly driven nexus resource potential. The rural and urban population in the study area has been increasing from 2005 to 2020, and also expected to increase up to 2035 with increasing demand of nexus resource (Figure 5). This population growth may also increase levels of poverty which results in unwise land use, water, energy and food.

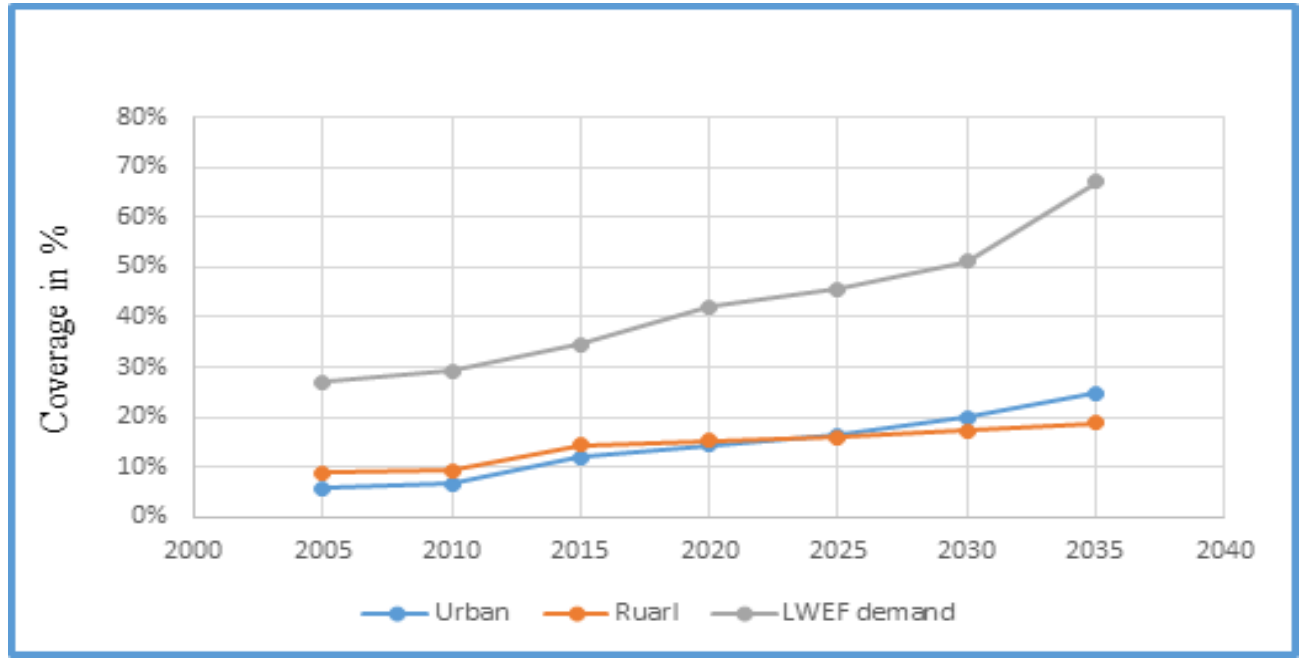

Figure 5. Population projection in the study area (data source: Central Rift Valley document) 
The relationship between population growth and nexus resource demand is changing and becoming complex due to increased consumption (Figure 5). It also shows the impact of urban and rural population growth on land, water, energy, and food nexus alongside socioeconomic and political factors. Such kind of population increase needs adopting an integrated method of monitoring the LWEF nexus for the studied landscape.

The current institutional setup and implementation of policies in land, water, energy and food nexus are still facing challenges in Ethiopia. However, it is the only option to restore degraded nexus resources. The country becomes the second most populated nation in Africa which needs additional food production, which could be obtained by intensive management of LWEF nexus resources. Karlberg et al (Karlberg et al., 2015) showed that while on-going agricultural intensification require more use of energy, the energy required by the majority of smallholder farmers comes from biomass sources rather than centralized energy infrastructure.

\subsubsection{Economic drivers}

An increase in nexus resource scarcity is linked with economic well-being. Low economic potential declines the quality and quantity of nexus resources which enforces human beings to deplete, convert, pollute or degrade nexus resources (Agboraw and Jones, 2017). Figure 6 depicts five economic nexus resource driving factor indicator.

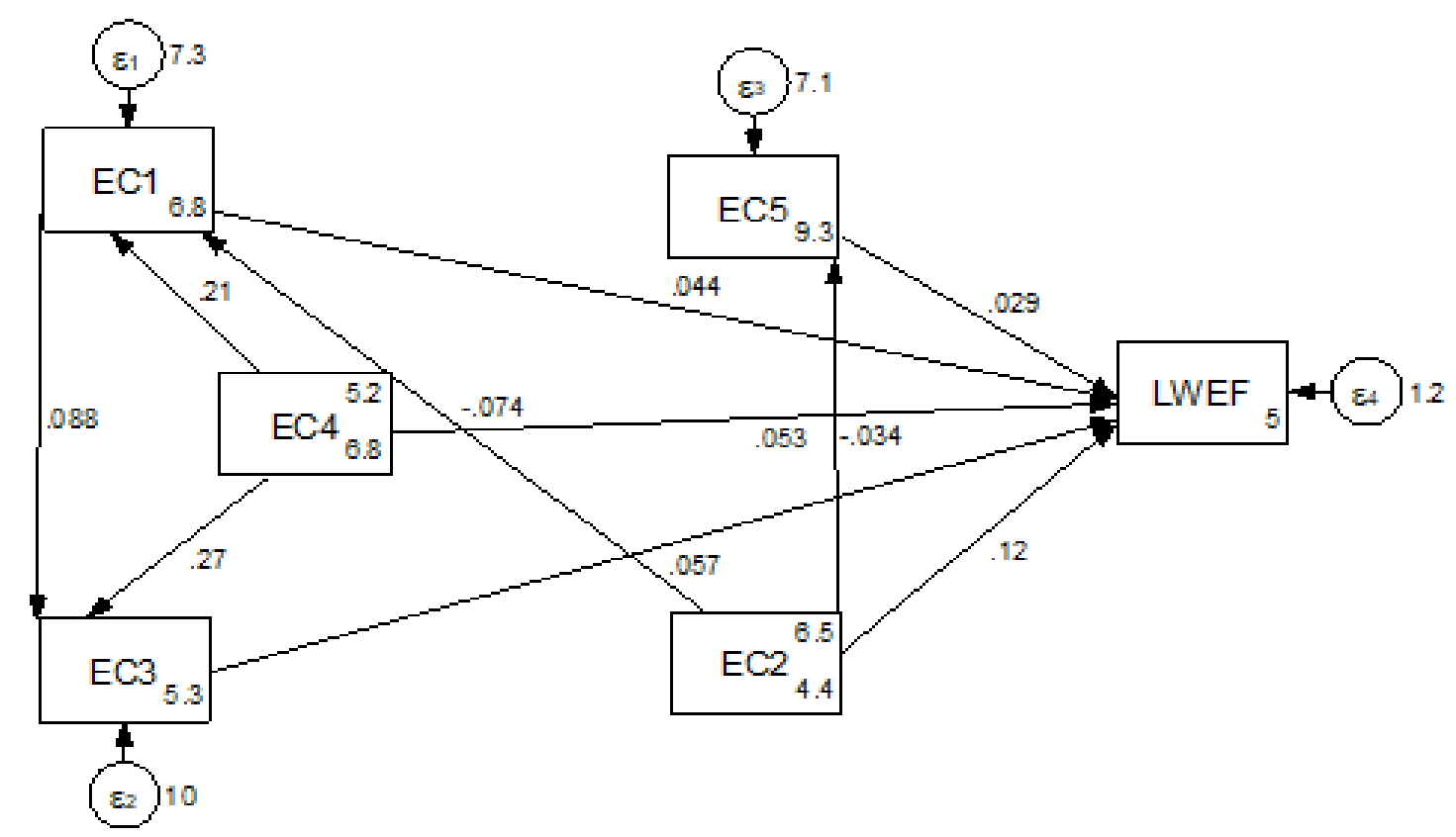

Figure 6. Economic driver indicator of $L W E F$ nexus resources $(E C 1=$ increasing income variability, EC2= local capital, EC3= increasing WEF prices, EC4= increasing land value, and EC5= inadequate financial resources) 
The weight of the driving factor indicator shows increasing income variability (EC1) and increasing WEF prices (EC3) are the dominant economic driving factors that affect nexus resources in the study area (Appendix table 1). The result of path coefficient analysis indicates that increasing income variability $(p=0.044)$ and increasing WEF prices $(p=0.057)$ have positive direct impact on LWEF nexus resource (Figure 6).

Regarding low capital (EC2), it has both direct $(p=0.12)$ and negative indirect $(p=-0.003)$ impacts on LWEF nexus resources (Figure 6). This necessitates governments to set capitals to stimulate economic activity to meet particular sectorial development goal. The low capital, which is the characteristics of low economic potential have taken the brunt of the blame by causing unsustainable use of nexus resources which is caused by low investment.

Therefore, the identification of pathway of economic driver impacts on LWEF nexus resource degradation, which requires an understanding of direct economic driver and solving it through prioritization. To incorporate this understanding the pathway between LWEF nexus degradation and economic driving factor indicator need to be mapped (Figure 6).

Increasing land value (EC4) indirectly drives $(p=0.015)$ LWEF nexus resources which are mediated by increasing income variability (Figure 6). The improper land use practices affect the availability of water, energy, and food which have environmental effects. This implies that due to economic development water and energy demand for food production is influenced by past land uses which in turn affect future land use. With this, the economic benefits of nexus resources by the local community have recently changed dramatically because wider forces such as overexploitation and unsustainable use permit them to do so.

\subsubsection{Environmental drivers}

A critical challenge for the environment over the coming decades is the demand for food production within the scarce land, water, and energy sources (Cosgrove and Loucks, 2015). Decline on those nexus resources will be risky for food production in the future than in the past due to complex driving factors.

Environmental driving factors have a complex character and they also exhibit different impacts on LWEF nexus resources. As pressure in the environment grows, the nexus resources might change; consequently, there might be an increase in the degradation process. According to Rijal et al. (2020), there may be different environmental driving factor indicator which selected in relation to the objectives and the prevailing condition. Table 1 shows the environmental driving factor indicator that affects nexus resources. These factors are fuelwood dependencies (EN1), charcoal production (EN2), agricultural expansion (EN3), land use change (EN4), climate change (EN5), and industrial expansion (EN6). 
The path coefficient analysis was carried out to estimate the direct and indirect effects of various environmental driving factors. Table 2 shows that industrial expansion $(p=0.326)$ exhibits the highest magnitude of direct effects on LWEF nexus, followed by climate change $(p=0.194)$ and agricultural land expansion $(p=0.172)$. These driving factors are considered as the principal factors that affect the LWEF nexus. In Table 2 fuel wood dependence had negative direct effect $(p=-0.038)$ and positive indirect effect on LWEF nexus which mediated by charcoal production $(\mathrm{p}=0.291)$, agricultural expansion $(p=0.059)$, land use change $(p=0.12)$, climate change $(p=0.066)$ and industrial expansion $(p=0.065)$.

As depicted in Table 2 the use of charcoal as energy sources had a negative direct $(p=-0.038)$ impact on LWEF nexus resources degradation, but it affects indirectly via agricultural expansion $(\mathrm{p}=0.001)$, land use change $(p=0.018)$, climate change $(p=0.075)$, and industrial expansion $(p=0.018)$. This indicates the use of charcoal as energy sources may affect nexus resources based on the extent of consumption; however, its integration with other factors may result in unintended impact. For example, land cover change induced by massive charcoal production affect land, water, energy and food production potential (Li et al., 2020). According to Sola et al. (2017) fuel wood collection and charcoal production is the main land resources driver in sub-Sahran Africa, the same is true in the current study area.

Table 2. Path coefficient analysis showing direct (bold) and indirect effect of six causal environmental driving factor indicator on LWEF nexus resources.

\begin{tabular}{lllllllll}
\hline Indicator & EN1 & EN2 & EN3 & EN4 & EN5 & EN6 & r & R $^{2}$ \\
\hline EN1 & $\mathbf{- 0 . 0 3 8}$ & 0.291 & 0.059 & 0.12 & 0.066 & 0.065 & $0.712^{*}$ & $0.809 *$ \\
EN2 & 0.06 & $\mathbf{- 0 . 0 7 5}$ & 0.001 & 0.018 & 0.075 & 0.018 & 0.669 & \\
EN3 & 0.012 & -0.304 & $\mathbf{0 . 1 7 2}$ & -0.021 & -0.009 & 0.089 & $0.876 *$ & \\
EN4 & 0.052 & 0.054 & -0.060 & $\mathbf{0 . 1 4 7} *$ & 0.004 & 0.120 & $0.342^{* *}$ & \\
EN5 & 0.290 & 0.038 & 0.021 & 0.089 & $\mathbf{0 . 1 9 4 * *}$ & -0.04 & 0.571 & \\
EN6 & 0.216 & -0.053 & 0.048 & 0.073 & 0.006 & $\mathbf{0 . 3 2 6} * *$ & 0.432 & \\
\hline
\end{tabular}

** values are significant at $p \leq 0.01 ; *$ values are significant at $p \leq 0.05, E N 1=$ fuel wood dependence, EN2 = charcoal production, EN3= agricultural land expansion, EN4= land use change, EN5= climate change, EN6= industrial expansion,

\subsubsection{Technology as driver}

Technological developments necessitate higher levels of productivity in terms of the use of land, water, and energy to increase food production. Technology can be expressed in various indicators, however, the current study identified four indicators based on expert's judgment and literature, such as lack of input supply (TC1), inadequate technology adoption and implementation (TC2), attitude towards technology innovation and development (TC3) and lack of infrastructure (TC4). 
Based on the weight of the indicator, lack of input supply (TC1) is ranked as the most important technology driver that imposes LWEF nexus in the study area (Appendix Table 1). Lack of access to technological input supply results in unproductive use of land, water, and energy resources (Kanianska, 2016). However, the technological processes may also produce unwanted results, such as loss of biodiversity, ecosystem disturbance, increased deforestation which create a trade-off on LWEF nexus. Table 3 exhibits TC1, TC2, TC3 have a significant correlation with LWEF nexus resources, while TC4 does not, which implies TC4 did not have a significant direct impact on LWEF nexus. Similarly, the path coefficient analysis shows that inadequate technology adoption and implementation $(p=0.198)$ reveals the highest magnitude of a direct impact on LWEF nexus resources, followed by an attitude towards technology innovation and development $(p=0.079)$ (Table 3). This implies inadequate technology adoption, implementation and low attitudes towards technology can limit proper use of land, water, and energy resources. Nowadays in Ethiopia due to lack of site-specific technology extension land wastage, irrigation water loss, and energy disruption are becoming serious problems in agreement with study of Bezuneh et al. (2013).

Table 3 depicts that the attitude towards technology innovation and development has significant indirect impact on nexus resources which is mediated by $\mathrm{TC} 1(p=0.001)$, TC2 $(p=0.818)$ and TC4 $(p=0.012)$. This implies people are causing environmental changes, notably in the biosphere, hydrosphere, and atmosphere which are associated with a lack of technology-based inputs supply, inadequate technology, and a lack of infrastructure. These changes are the result of human activities linked with time and space, leading to global environmental problems.

Table 3. Path coefficient analysis for direct (bold) and indirect effect of technology indicator as LWEF nexus resource driver.

\begin{tabular}{ccccccc}
\hline Indicator & TC1 & TC2 & TC3 & TC4 & r & $\mathrm{R}^{2}$ \\
\hline TC1 & $\mathbf{- 0 . 2 9 9 * *}$ & 0.001 & $0.015 * *$ & -0.031 & $0.907 * *$ & $0.907 *$ \\
TC2 & 0.014 & $\mathbf{0 . 1 9 8 * *}$ & 0.002 & -0.002 & $0.147 * *$ & \\
TC3 & $0.001 *$ & $0.818^{*}$ & $\mathbf{0 . 0 7 9 *}$ & 0.012 & $0.316^{* *}$ & \\
TC4 & 0.04 & -0.012 & 0.001 & $\mathbf{0 . 0 2 3}$ & 0.215 & \\
\hline
\end{tabular}

** values are significant at $p \leq 0.01 ; *$ values are significant at $p \leq 0.05 ; T C 1=$ lack of input supply, TC2 = inadequate technology adoption and implementation, TC3= attitude towards technology innovation and development, TC4= lack of infrastructure.

In general, one of the major causes of prolonged environmental problems is a technology and how humans use it since it can be both source and remedy of environmental problems. It also plays a critical role as an instrument for observing and monitoring the environment on global and local scales, in agreement with the finding of (Ferreira et al., 2020) 


\subsubsection{Institutional and policy change as a driver}

Aligned institutional structure and policy help to utilize nexus resources effectively, efficiently, and equitably. However, to date, the institutional structure and policy to integrate and manage the LWEF system as one component in Ethiopia entangled with complex problems of relevance, quality, accessibility and equity (Flintan and Tedla, 2010), which results in land, water, energy, and food insecurity.

Even though institutions and policy are working on Ethiopian forests, in the last three decades, the forest cover of the country drops from $40 \%$ to $3 \%$ (Gebrehiwot et al., 2014). This is linked with unintended institutional and policy change which induce land degradation, results on WEF nexus insecurity across the country.

The causes of failure in nexus resources insecurity were linked with frequent institutional and policy change. These changes became LWEF resource drivers (Table 1). Based on the literature review and consultation with expert's we consider outdated legislation (IP1), inadequate financial capital (IP2), poor institutional structure (IP3), and poor stakeholder network (IP4) as the common institutional and policy change indicators that affect the LWEF nexus.

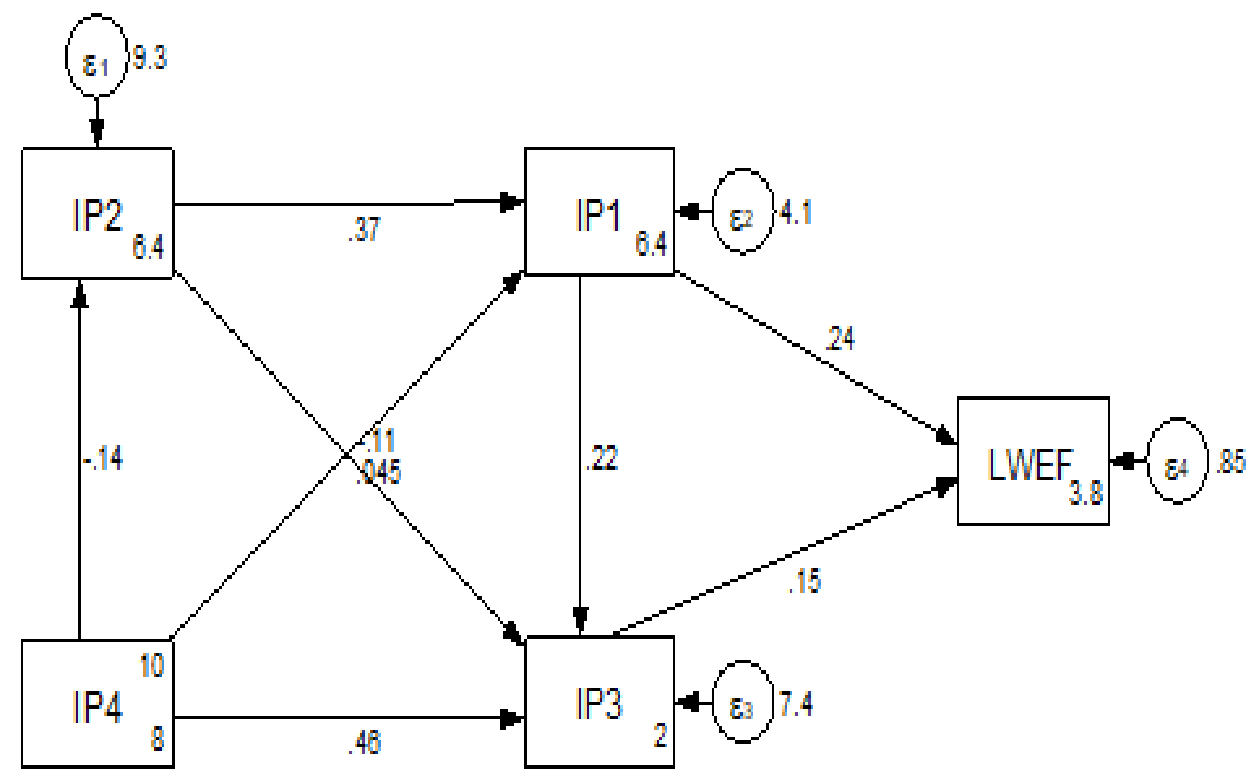

Figure 7. The direct and indirect impact of institutional and policy change driver on LWEF nexus (Outdated legislation (IP1), inadequate financial capital (IP2), poor institutional structure (IP3) and poor stakeholder network (IP4))

According to Nyberg-Sørensen et al. (2002) the nexus approach is becoming gradually prominent on policymakers' agenda at the global and national level. However, in Ethiopia, 
particularly, in the case study area, inclusive outdated legislation among land, water, energy and food sectors is challenging. This could be due to those sector applies different concepts and contrasting types of interaction from the budget allocation, management scope, and organogram. Such differences prevent shared understanding which manipulates LWEF resources.

The result of the analysis indicates that outdated legislation $(p=0.24)$ and poor institutional structure $(p=0.15)$ directly affect LWEF nexus resources (Figure 7). Lack of updating regulation and performing institution on the basis of time and resource use, with the current era of increasing population adequately disrupt the balance between resource and resource usage. Inadequate financial capital indirectly affects LWEF nexus resources through outdated legislation $(p=0.089)$ and poor institutional structure $(\mathrm{p}=0.008)$. These results depict most programs, projects and activities did not aim to set in place the conditions under which local communities will be economically willing, and able, to conserve LWEF resources, results in nexus resource degradation by placing unsustainable demands on natural resources.

Poor stakeholder network affects nexus resources indirectly through outdated legislation $(p=$ $-0.026)$ and poor institutional structure $(p=0.07)$ (figure 7$)$. In the last two decades many policies and projects designed in the current study area have not achieved LWEF nexus security due to poor stakeholder network. Lack of understanding institutional and policy changes as driving factors influences nexus resources consumption, regulation and management which results in negative externalities across sectors.

Figure 8 reveals comprehensive model fitness statistics for five main LWEF nexus resources driving factors indicators. The result of the analysis indicates that except for institutional and policy change, other main driving factors directly affect LWEF nexus resources. Additionally, economic, social, and environmental driving factors also indirectly affect LWEF nexus resources.

The result of the path coefficient analysis revealed that economic $(p=0.025)$ and social $(p=0.011)$ driving factors had a positive direct effect on LWEF nexus resource degradation (Figure 8). This implies LWEF resource degradation often results from immediate causes such as economic crisis and unsustainable resource management practices, or with underlying causes including population density, poverty, lack of alternative livelihoods, and consumption patterns.

Institutional and policy change indirectly affect LWEF nexus resources by enhancing or reducing technological advancement. Similarly, social structure and characteristics need a 
binding policy in order to regulate unsustainable resource utilization activities that contribute to natural degradation.

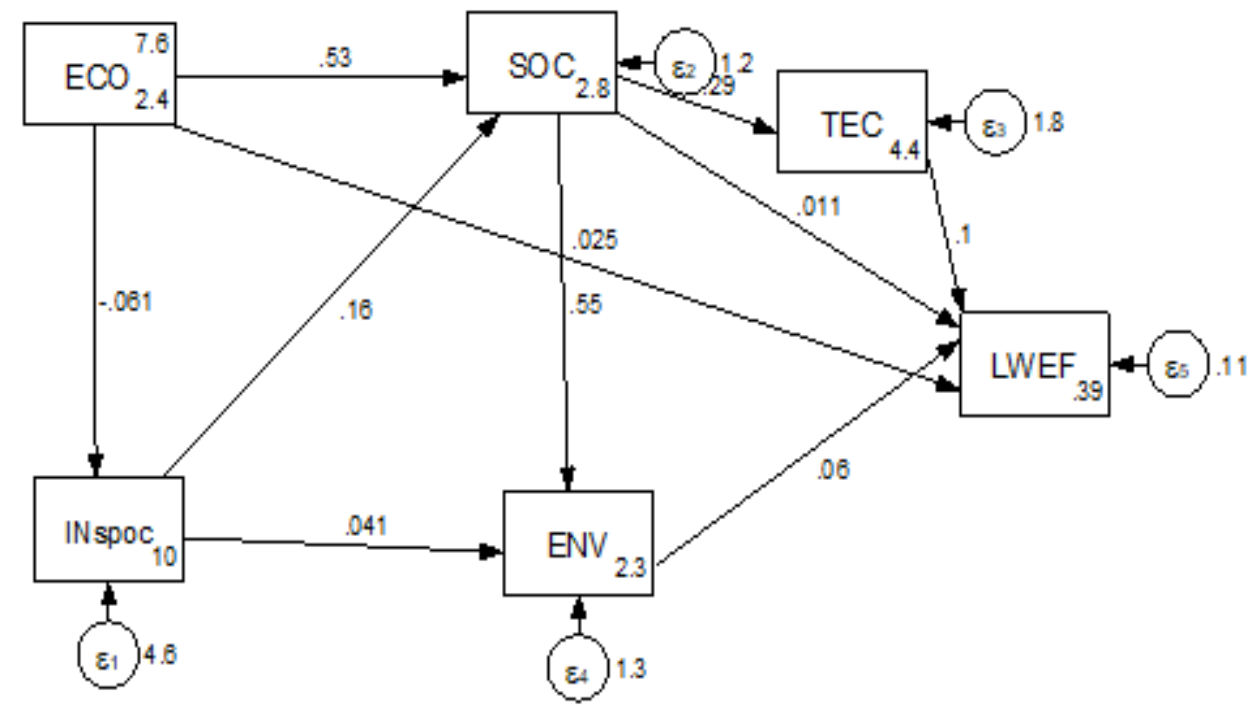

Figure 8. The final comprehensive path model which tested how main driving factor indicator affect LWEF nexus. The indices of model fit demonstrated excellent goodness-offit $\left(X_{(6)}^{2}=7.24, p=0.31, T L I=0.99 ; N F I=0.92 ; R M S E A=0.03\right)$ and all paths in the model are significant at $p<0.05$

\subsection{Impact of LWEF nexus degradation on socio-economy, livelihoods and ecology}

Nexus resource degradation refers to the impairment of natural quality and quantity of nexus resource which affect human well-being (Aggrey et al., 2010). It is the common problem in Ethiopia, particularly in the case study area characterized by declining land productivity, water availability, energy sources and continuing food insecurity.

In the study area, there are losses of biological and economic productivity caused by the complexity of land uses, water, energy access, and food insecurity. This could be associated with rapid population increase, urbanization and climate change which will pose a huge pressure on the socio-economic, ecological, and livelihood of the local community (Chung et al., 2011).

\subsubsection{Socio-economic impact}

Land, water, energy, and food resources are critical for the development and survival of societies (Liu et al., 2017). However, access to these resources is complicated by factors driving nexus resource degradation. According to Mohamed (2017), following the complexity of LWEF nexus resource, more than 18.1 million people in Ethiopia are forced 
for frequent nexus resource insecurity which will affect different socio-economic components.

The result shows that access/availability of food (34.6\%), overall electric supply (26\%), and poor health conditions (10.57\%) are key socio-economic characteristics strongly affected by LWEF nexus degradation in the study area (Table 3). LWEF nexus degradation affects access/availability of food by $34.6 \%$ as compared with other socio-economic characteristics (Table 4). This implies that land use change, water and energy crisis challenges food security under changing climatic conditions. Understanding sustainable management of land, water and energy is one of the keystones for establishing livelihood security, maintaining the provision of ecosystem services and adaptive capacity against nexus resource degradation.

Table 4. Impact of LWEF nexus degradation on socio-economic characteristics in the

\begin{tabular}{|c|c|c|c|c|}
\hline S/No & $\begin{array}{l}\text { Socio-economic } \\
\text { characteristics }\end{array}$ & Mean & Standard dev. & $\%$ of impact \\
\hline 1 & Age & 9.2 & 2.67 & 8.11 \\
\hline 2 & Gender & 7.4 & 2.76 & 0.14 \\
\hline 3 & Population density & 6.53 & 2.1 & 0.04 \\
\hline 4 & $\begin{array}{l}\text { Economic capacity of } \\
\text { household }\end{array}$ & 7.39 & 3.31 & 0.04 \\
\hline 5 & Level of education & 5.6 & 2.61 & 8.85 \\
\hline 6 & Poor health condition & 10.28 & 2.83 & 10.57 \\
\hline 7 & Access to productive land & 8 & 3.07 & 0.04 \\
\hline 8 & Overall electric supply & 4.97 & 3.07 & 26.0 \\
\hline 9 & Access to clean water & 8.65 & 2.31 & 4.5 \\
\hline 10 & Institutional development & 8.42 & 3.06 & 0.004 \\
\hline 11 & Access/ availability of food & 8.78 & 2.53 & 34.6 \\
\hline 12 & Access to irrigation water & 10.6 & 3.94 & 7.1 \\
\hline
\end{tabular}

Socio-economic characteristics such as age $(8.11 \%)$, poor health condition $(10.57 \%)$, and level of education (8.85\%) affected by LWEF nexus resource degradation (Table 4). Nexus resource degradation affects socio-economic conditions of human wellbeing, characterized by a poor health condition, low level of education, low food supply (Wolde et al., 2020). The current study area has good water potential compared with other nexus resources however, irrigation water potential was reduced by $7.1 \%$ due to land use change (Table 4 ). This causes the population in the study area to continuously depends on food aid, supported by USAID (MOHAMMED, 2016).

\subsubsection{Ecological impact}

Due to resultant nexus resource degradation in the study area ecological balance was disturbed, which characterized by loss of biodiversity and migration of rural people to search for additional land, water and food. 
Land, water, energy and food degradation also interrupts the regulating and provisioning services of the ecosystem, in particular through agro-ecological variations, climate change, forest loss, gully formation, soil erosion, loss of biodiversity, and drying of wetland (Coates et al., 2013). During our field investigation, the farming community reported that land use change, water potential reduction, lack of fuel wood, and declining food production was observed in the last four decades. Following this ecological variation in 2017 frost occurrence was observed in the highland part of the study area that affected the major livelihoods of the local community by declining productivity of crops particularly coffee and Enset (Figure 9).

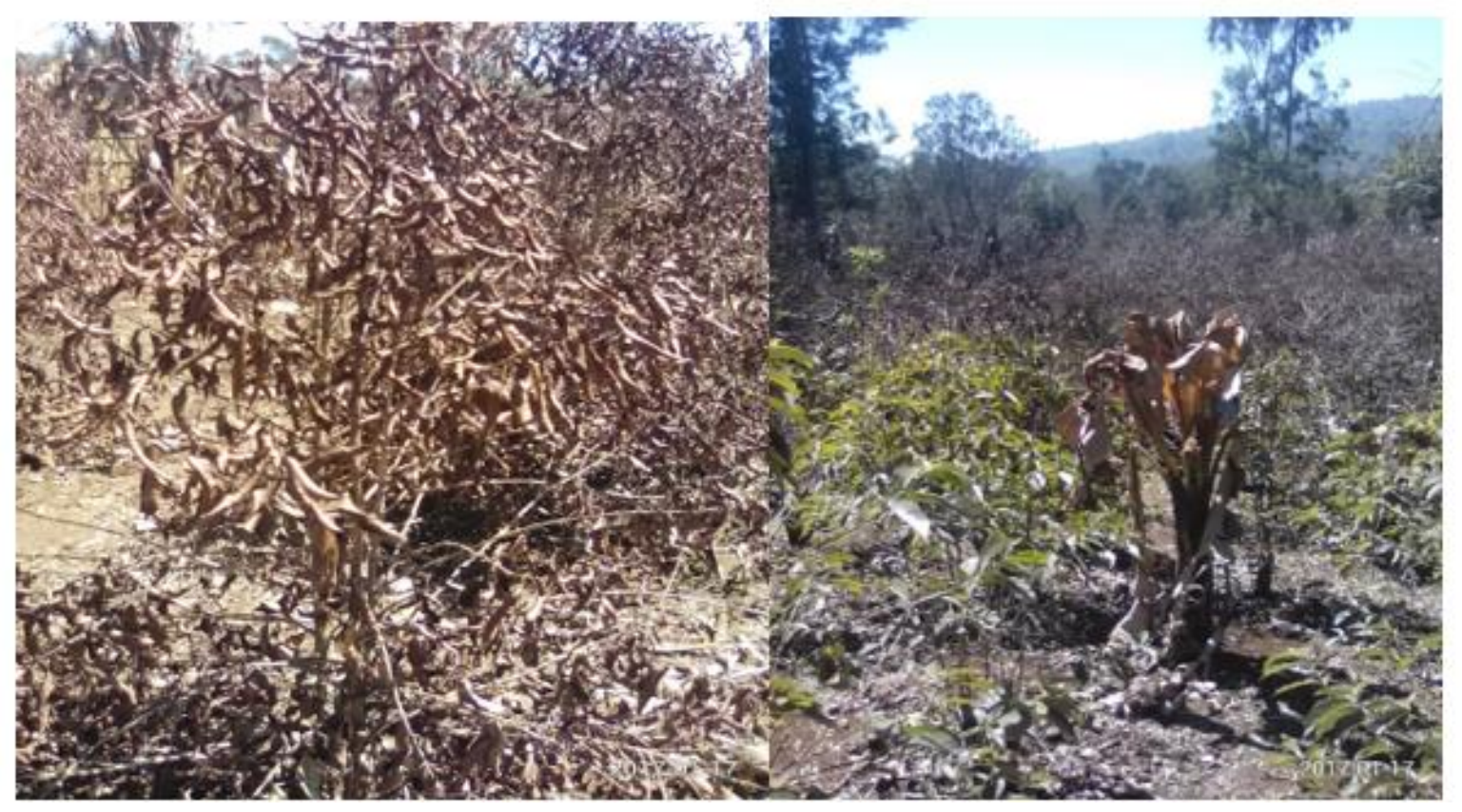

Figure 9. The impact of frost due to climatic variability in the highland part of Gidabo watershed

Climate change caused by nexus resource degradation reduces ecological efficiency to supply productive land, sufficient water, safe energy and food (Figure 10). The study area has been subjected to drastic ecological change attributed to climate change, forest loss, loss of biodiversity and low agricultural productivity which affect the overall environment (Figure $10)$.

The threats to ecology arise because of change in the quality and quantity of LWEF nexus which underpin all ecological processes (Wolde et al., 2020), and lack of stakeholders to invest in nexus resources result on low conservation of biological diversity and ecological integrity. 


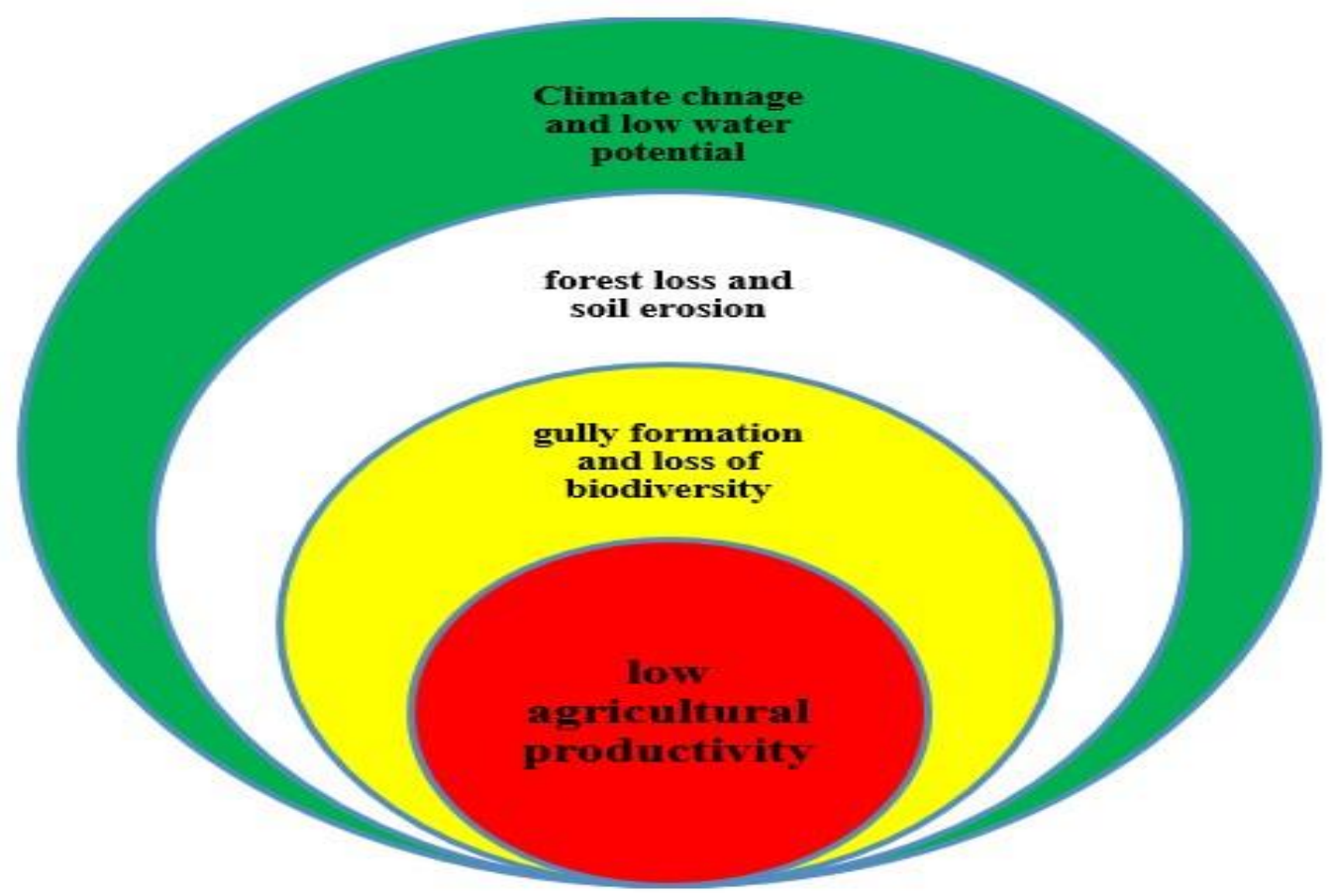

Figure 10. LWEF nexus resources degradation impact on ecological characteristics

Figure 10 reveals that climate change and low water potential, forest loss, and soil erosion, gully formation and biodiversity loss and low agricultural productivity are all interdependent characteristics of ecological degradation because any action on one of these characters can affect others. Climate change and low water potential ascertained by forest loss and soil erosion, it may also affect land use and loss of biodiversity. Most important is that low agricultural productivity, from the nexus component, food production is highly affected by climate change, and low water potential, forest loss and soil erosion and loss of ecosystem.

\subsubsection{Livelihood impact}

The livelihoods of rural communities entirely depend on the availability and consumption of land, water, energy and food nexus resources, which directly or indirectly affect the livelihoods activities (Table 5). We used a structured household survey to explore how livelihoods affected by nexus resource degradation. Table 5 summarizes the response of 434 households on how LWEF nexus degradation affects livelihoods.

As shown in Table 5, crop production (38.1\%), livestock rearing (16.3\%), and agroforestry practices $(10.4 \%)$ were the major livelihood activities affected by LWEF nexus resource degradation in the study area. We are unable to obtain exact details about the size and extent of impacts during the interview. However, crop production and livestock are potential livelihoods are affected by nexus resource degradation. Spiegelberg et al. (2017) reported 
that sustainable management of WEF nexus is one of the keystones for establishing livelihood security.

Beekeeping (5.29\%), fishing (9.9\%) and fruit production $(7.5 \%)$ are also an important livelihoods activity affected by the degradation of nexus resources (Table 5). Therefore, LWEF nexus resource degradation hampered the livelihoods of rural communities and becoming a major challenge for sustainable development.

Most rural poor are smallholders practicing low-input agricultural production, which need a substantial amount of productive land, water and energy. Lack of these nexus resources could have triggered a reduction in food production, energy, and water access.

Energy insecurity is a significant challenge in the study area which affects the expansion of the school, health center, institutional structure and other. Furthermore, the lack of available land, water and energy affects small-enterprise by $12.5 \%$ (table 5), which is a source of income for the rural community.

Table 5. An overview of the livelihoods activities affected by LWEF nexus degradations which were assessed using household surveys $(\mathrm{N}=434)$.

\begin{tabular}{llll}
\hline $\begin{array}{l}\text { Livelihoods } \\
\text { activities }\end{array}$ & mean & Standard deviation & Frequency $(\%)$ \\
\hline Crop production & 23.75 & 2.97 & 38.10 \\
Agroforestry & 10.8 & 2.4 & 10.40 \\
Livestock & 18.95 & 4.98 & 16.30 \\
Beekeeping & 11.29 & 6.98 & 5.29 \\
Fishing & 13.21 & 6.18 & 9.90 \\
Fruit production & 9.05 & 4.78 & 7.50 \\
Small-enterprise & 12.24 & 4.03 & 12.50 \\
\hline
\end{tabular}

Due to a combination of driving factors and human influences rural livelihoods are characterized by extreme uncertainty and seasonality of land, water, energy and food nexus resources, as reported by (Wolde et al., 2020).

Generally, policymakers in the land, water, energy and food sector need to gauge the influence of the driving factors on LWEF nexus resources in order to identify the problem and carry out effective strategies. In this context, the identification of drivers of LWEF nexus is essential not only for small geographical unity, but also for the sustainable management of basic nexus resource potential in the long run.

\section{Conclusion}

Nowadays in accelerated global socio-environmental change the land, water, energy and food nexus has received increasing attention in academia and policymakers to restore nexus 
resource degradation. However, identification of nexus driving factor was limited and can result in degradation of nexus resources.

In this study, we closely identified land, water, energy and food nexus resource driving factors indicators to show the concept of the current nexus resources trade-off. The analysis of the weight of nexus resources indicators shows that social (such as; population growth, poverty, lack of alternative livelihoods etc.), economic (increasing income variability and WEF prices), and institutional and policy change (outdated legislation) are the major drivers of nexus resource. This indicates a lack of understanding the social, economic, and institutional and frequent policy change induce LWEF nexus resources degradation.

We argue that many nexus discourses focus on population growth and urbanization as a major nexus resource driver. However, these drivers were studied from a macro scale and growing megacities for the last decades, but the variability of these drivers from region to region was under looked at and needs policy attention. Therefore, this study focuses on understanding social, economic, environmental, institutional and policy change, and technology as a driver which induce degradation.

The result of the analysis indicates that in the study area LWEF nexus resources are significantly influenced by eight direct driving factors (such as SC1, SC2, EC1, EC2, EC4, EN3, EN4, and TC2), while other affects indirectly. These analyzed driving factors and their effects help stakeholders to better plan and design relevant policies to keep synergy and tradeoff for sustainable nexus resources management.

The finding of this study can also share experiences for nexus resources driving factor from local to a national scale, which can be of interest to the audience of nexus resource managers and planners to provide a better opportunity to reduce pressure on LWEF nexus resources. Managing identified driving factor is essential to protect LWEF nexus resources which have a close link with human health and the environment. Addressing the adverse effects of driving factors needs all stakeholders to make a permanent individual and collective commitment which protect the environment and reduce the impact of driving factor on the environment and public health. Furthermore, we underline the necessity of applying LWEF nexus approaches to manage those drivers, in order to optimize environmental and social outcomes. For future research, different driving factor indicators and their impacts can be used to define benchmarks to identify the requirement of sustainable LWEF nexus for different parts of the country.

\section{Acknowledgment}


We are grateful to the Chinese Government Scholarship Council (CSC) for giving the first author a chance to pursue his Ph.D. study in China. The authors are also indebted to the thanks International Cooperation and Cultivation Project of Nanjing Agricultural University (Fund No. X201915) which enabled to conduct this research.

\section{Conflicts of Interest:}

The authors declare no conflict of interest.

\section{Ethical approval}

Not Applicable

\section{Consent to participate}

Not applicable

\section{Consent to publish}

Not applicable

\section{Funding}

This study is funded by International Cooperation and Cultivation Project of Nanjing Agricultural University (Fund No. X201915) and International Cooperation and Cultivation Project of Nanjing Agricultural University (Fund No. X201915)

\section{Authors Contribution}

Conceptualization, Z.W and W.W.; methodology, Z.W\&EY.; software, ZW\&HT.; validation, Z.W \&HT, WW and H.K.; formal analysis, ZW.; investigation, ZW.; resources, ZW.; data curation, Z.W, HK; writing-original draft preparation, Z.W\&HT.; writing-review and editing, Z.W and WW; visualization, ZW.; supervision, WW.; project administration, WW.; funding acquisition, WW. All authors have read and agreed to the published version of the manuscript.

\section{Availability of data and material}

Not applicable 


\begin{tabular}{|c|c|c|c|c|c|c|c|c|c|c|c|c|c|c|c|c|c|c|c|c|c|c|c|c|c|}
\hline $\bar{\omega}$ & స్ & U్ర & J্ & 己ֶ & ర্) & $\underbrace{}_{I I}$ & $\underset{I}{\tilde{I}}$ & $\bigcup_{I I}^{O}$ & $\underset{I}{J}$ & $\bigcup_{1=1}^{D}$ & $\bar{\Xi}$ & $\cong$ & $\stackrel{\varrho}{\Leftrightarrow}$ & 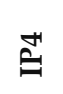 & $\underset{r}{Z}$ & $\underset{r}{Z}$ & $\sum_{I I}^{m}$ & $\sum_{r=1}^{H}$ & $\sum_{\square}^{n}$ & $Z_{I}^{\mathscr{Z}}$ & $\tilde{U}^{\tilde{U}}$ & $\underset{H}{\tilde{U}}$ & $\bigcup_{0}^{0}$ & $\underset{H}{J}$ & $\begin{array}{l}50 \\
3 \\
3\end{array}$ \\
\hline \multirow[t]{25}{*}{1} & $1 / 5$ & $1 / 3$ & $1 / 7$ & 4 & $1 / 5$ & $1 / 2$ & 1 & $1 / 4$ & $1 / 8$ & 7 & $1 / 9$ & 1 & 3 & $1 / 2$ & 2 & $1 / 3$ & 5 & 3 & 2 & 3 & 5 & $1 / 7$ & $1 / 8$ & $1 / 9$ & 0.118 \\
\hline & 1 & $1 / 4$ & 6 & 8 & $1 / 4$ & 1 & 1 & 4 & $1 / 2$ & $1 / 2$ & $1 / 2$ & $1 / 3$ & 1 & 3 & 1 & 2 & 2 & $1 / 6$ & 4 & $1 / 3$ & 7 & 1 & 2 & 4 & 144 \\
\hline & & 1 & $1 / 3$ & $1 / 3$ & $1 / 2$ & $1 / 4$ & $1 / 3$ & 2 & $1 / 4$ & $1 / 2$ & 1 & $1 / 2$ & 1 & 2 & $1 / 2$ & 3 & 2 & 5 & $1 / 5$ & $1 / 2$ & $1 / 6$ & $1 / 2$ & 2 & 3 & 065 \\
\hline & & & 1 & $1 / 4$ & 1 & $1 / 5$ & 2 & $1 / 3$ & $1 / 5$ & 2 & 2 & $1 / 5$ & 3 & 2 & 1 & 1 & 2 & 3 & 6 & 3 & 1 & 3 & 2 & 1 & 063 \\
\hline & & & & 1 & $1 / 3$ & 3 & 5 & 2 & 3 & $1 / 2$ & $1 / 2$ & 2 & 1 & 1 & 2 & 7 & $1 / 4$ & 1 & 3 & $1 / 7$ & 1 & 1 & 2 & 3 & 81 \\
\hline & & & & & 1 & 5 & 3 & 5 & $1 / 2$ & $1 / 2$ & 2 & 3 & 2 & 6 & 3 & 4 & 2 & $1 / 2$ & 1 & $1 / 3$ & 5 & $1 / 7$ & 5 & $1 / 2$ & .096 \\
\hline & & & & & & 1 & 2 & 3 & $1 / 3$ & 3 & $1 / 5$ & 5 & 1 & 2 & 6 & 1 & 3 & $1 / 5$ & $1 / 4$ & 7 & $1 / 5$ & 6 & 5 & 1 & .067 \\
\hline & & & & & & & 1 & 2 & $1 / 3$ & $1 / 2$ & 3 & $1 / 2$ & $1 / 2$ & 1 & 3 & 1 & $1 / 5$ & 3 & $1 / 5$ & 1 & $1 / 3$ & $1 / 2$ & $1 / 2$ & $1 / 3$ & .031 \\
\hline & & & & & & & & 1 & $1 / 5$ & 1 & 3 & $1 / 5$ & 1 & $1 / 5$ & 1 & $1 / 3$ & $1 / 2$ & 4 & 2 & 6 & 1 & 3 & 3 & 6 & 0.037 \\
\hline & & & & & & & & & 1 & $1 / 2$ & $1 / 3$ & $1 / 6$ & 2 & $1 / 2$ & 4 & $1 / 5$ & 3 & 2 & 1 & 2 & 3 & $1 / 4$ & $1 / 5$ & 1 & .028 \\
\hline & & & & & & & & & & 1 & $1 / 2$ & 2 & 1 & $1 / 3$ & $1 / 5$ & 3 & 2 & 1 & 3 & 3 & $1 / 2$ & $1 / 2$ & 2 & 3 & 24 \\
\hline & & & & & & & & & & & 1 & 3 & 4 & $1 / 6$ & $1 / 2$ & $1 / 3$ & $1 / 5$ & 4 & 5 & 1 & $1 / 2$ & $1 / 2$ & 5 & 7 & 0.033 \\
\hline & & & & & & & & & & & & 1 & 2 & 5 & 1 & 2 & $1 / 6$ & 5 & 1 & 5 & 3 & 5 & 6 & 3 & 0.038 \\
\hline & & & & & & & & & & & & & 1 & $1 / 9$ & 5 & 3 & 7 & 6 & 5 & 2 & $1 / 2$ & 3 & $1 / 3$ & 4 & .033 \\
\hline & & & & & & & & & & & & & & 1 & $1 / 2$ & 6 & 6 & 4 & 4 & $1 / 3$ & 3 & $1 / 3$ & 7 & $1 / 2$ & .027 \\
\hline & & & & & & & & & & & & & & & 1 & 7 & $1 / 2$ & $1 / 2$ & 6 & 5 & 5 & 3 & 5 & 6 & 0.030 \\
\hline & & & & & & & & & & & & & & & & 1 & 5 & 7 & 5 & 4 & $1 / 3$ & 4 & 4 & 2 & 0. \\
\hline & & & & & & & & & & & & & & & & & 1 & 5 & 6 & $1 / 6$ & $1 / 4$ & 1 & $1 / 3$ & $1 / 2$ & 0.010 \\
\hline & & & & & & & & & & & & & & & & & & 1 & 7 & 4 & 5 & 4 & $1 / 2$ & 6 & .020 \\
\hline & & & & & & & & & & & & & & & & & & & 1 & 1 & 6 & 2 & 2 & $1 / 5$ & 0.0 \\
\hline & & & & & & & & & & & & & & & & & & & & 1 & 2 & 5 & 1 & 4 & 0 \\
\hline & & & & & & & & & & & & & & & & & & & & & 1 & $1 / 6$ & 1 & 6 & 0.005 \\
\hline & & & & & & & & & & & & & & & & & & & & & & 1 & 2 & $1 / 3$ & \\
\hline & & & & & & & & & & & & & & & & & & & & & & & 1 & 2 & 0.002 \\
\hline & & & & & & & & & & & & & & & & & & & & & & & & 1 & .001 \\
\hline
\end{tabular}




\section{References}

Abel, C., Horion, S., Tagesson, T., De Keersmaecker, W., Seddon, A.W., Abdi, A.M., Fensholt, R. (2020) The human-environment nexus and vegetation-rainfall sensitivity in tropical drylands. Nature Sustainability, 1-8.

Agboraw, E., Jones, A., (2017) Economics and Natural Resource Constraints, Resource Constraints and Global Growth. Springer, pp. 5-40.

Aggrey, N., Wambugu, S., Karugia, J., Wanga, E. (2010) An investigation of the poverty-environmental degradation nexus: a case study of Katonga Basin in Uganda. Research Journal of Environmental and Earth Sciences 2, 82-88.

Al-Saidi, M., Elagib, N.A. (2017) Towards understanding the integrative approach of the water, energy and food nexus. Science of the Total Environment 574, 1131-1139. Ali, M.H., Zailani, S., Iranmanesh, M., Foroughi, B. (2019) Impacts of environmental factors on waste, energy, and resource management and sustainable performance. Sustainability 11, 2443.

Amenu, B.T. (2017) Assessments of the Effects of Land Degradation on Freshwater and Local Communities Participation in Essera District, Dawro Zone, South Western Ethiopia. American Journal of Natural Sciences 1, 1-20.

Bakhshianlamouki, E., Masia, S., Karimi, P., van der Zaag, P., Sušnik, J. (2020) A system dynamics model to quantify the impacts of restoration measures on the waterenergy-food nexus in the Urmia lake Basin, Iran. Science of the Total Environment 708, 134874.

Barbier, E.B., Hochard, J.P. (2018) Land degradation and poverty. Nature Sustainability 1, 623-631.

Bezuneh, T., Hailemariam, S., Zeleke, G., Ababa, A. (2013) Science and Technology in Ethiopia.

Chang, Y., Li, G., Yao, Y., Zhang, L., Yu, C. (2016) Quantifying the water-energy-food nexus: Current status and trends. Energies 9, 65.

Chen, B., Han, M., Peng, K., Zhou, S., Shao, L., Wu, X., Wei, W., Liu, S., Li, Z., Li, J. (2018) Global land-water nexus: agricultural land and freshwater use embodied in worldwide supply chains. Science of The Total Environment 613, 931-943.

Chouksey, N., Mishra, G., Chouksey, R. (2020) Path Analysis in Rice Yield and Yield Attributing Characters by Structural Equation Model. Int. J. Curr. Microbiol. App. Sci 9, 3098-3103.

Chung, E.S., Park, K., Lee, K.S. (2011) The relative impacts of climate change and urbanization on the hydrological response of a Korean urban watershed. Hydrological processes 25, 544-560.

Coates, D., Pert, P.L., Barron, J., Muthuri, C., Nguyen-Khoa, S., Boelee, E., Jarvis, D.I. (2013) Water-related ecosystem services and food security. Managing water and agroecosystems for food security 10, 29.

Collomb, J., Mupeta, P., Barnes, G., Child, B. (2010) Integrating governance and socioeconomic indicators to assess the performance of community-based natural resources management in Caprivi (Namibia). Environmental Conservation, 303-309. Cosgrove, W.J., Loucks, D.P. (2015) Water management: Current and future challenges and research directions. Water Resources Research 51, 4823-4839. 
49 Costa, R.C.A., Pereira, G.T., Pissarra, T.C.T., Siqueira, D.S., Fernandes, L.F.S., 50 Vasconcelos, V., Fernandes, L.A., Pacheco, F.A.L. (2019) Land capability of multiple51 landform watersheds with environmental land use conflicts. Land use policy 81, 68952704.

53 Dale, V.H., Beyeler, S.C. (2001) Challenges in the development and use of 54 ecological indicators. Ecological indicators 1, 3-10. dellano-Paz, F., Fernandez, P.M., Soares, I. (2019) 4.2 Paper 1: Addressing 2030 EU policy framework for energy and climate: Cost, risk and energy security issues. An application of the Modern Portfolio Theory to the optimization of the European Union power generation mix from an environmental perspective 115, 41.

Delucchi, M. (2010) Impacts of biofuels on climate change, water use, and land use. Annals of the New York Academy of Sciences 1195, 28.

61 Dibaba, W.T., Demissie, T.A., Miegel, K. (2020) Drivers and Implications of Land 62 Use/Land Cover Dynamics in Finchaa Catchment, Northwestern Ethiopia. Land 9, $63 \quad 113$.

64 Ding, T., Liang, L., Zhou, K., Yang, M., Wei, Y. (2020) Water-energy nexus: The origin, development and prospect. Ecological Modelling 419, 108943.

66 Dogan, E., Madaleno, M., Altinoz, B. (2020) Revisiting the nexus of financialization and natural resource abundance in resource-rich countries: New empirical evidence from nine indices of financial development. Resources Policy 69, 101839. Duan, C., Chen, B. (2020) Driving factors of water-energy nexus in China. Applied Energy 257, 113984. Estoque, R.C., Togawa, T., Ooba, M., Gomi, K., Nakamura, S., Hijioka, Y., Kameyama, $Y$. (2019) A review of quality of life (QOL) assessments and indicators: Towards a "QOL-Climate" assessment framework. Ambio 48, 619-638.

Ferreira, J.J., Fernandes, C.I., Ferreira, F.A. (2020) Technology transfer, climate change mitigation, and environmental patent impact on sustainability and economic growth: A comparison of European countries. Technological Forecasting and Social Change 150, 119770.

Flintan, F., Tedla, S. (2010) Natural resource management: The impact of gender and social issues. IDRC, Ottawa, ON, CA.

Fraser, E.D., Dougill, A.J., Mabee, W.E., Reed, M., McAlpine, P. (2006) Bottom up and top down: Analysis of participatory processes for sustainability indicator identification as a pathway to community empowerment and sustainable environmental management. Journal of environmental management 78, 1 14-127. Gebrehiwot, S.G., Bewket, W., Gärdenäs, A.I., Bishop, K. (2014) Forest cover change over four decades in the Blve Nile Basin, Ethiopia: comparison of three watersheds. Regional Environmental Change 14, 253-266.

87 Graham, M.H. (2003) Confronting multicollinearity in ecological multiple regression. 88 Ecology 84, 2809-2815.

89 Granit, J., Jägerskog, A., Lindström, A., Björklund, G., Bullock, A., Löfgren, R., de 90 Gooijer, G., Pettigrew, S. (2012) Regional options for addressing the water, energy 
and food nexus in Central Asia and the Aral Sea Basin. International Journal of Water Resources Development 28, 419-432.

Gulati, M., Jacobs, I., Jooste, A., Naidoo, D., Fakir, S. (2013) The water-energy-food security nexus: Challenges and opportunities for food security in South Africa. Aquatic Procedia 1, 150-164.

Hathaway, T., (2008) What cost Ethiopia's dam boom? A look inside the expansion of Ethiopia's energy sector. International Rivers, People, Water, Life.

Helmy, I., (2020) Livelihood Diversification Strategies: Resisting Vulnerability in Egypt. GLO Discussion Paper.

Heuss, L., Grevé, M.E., Schäfer, D., Busch, V., Feldhaar, H. (2019) Direct and indirect effects of land-use intensification on ant communities in temperate grasslands. Ecology and evolution 9, 4013-4024.

Imasiku, K., Ntagwirumugara, E. (2020) An impact analysis of population growth on energy-water-food-land nexus for ecological sustainable development in Rwanda. Food and Energy Security 9, e185.

Kanianska, R. (2016) Agriculture and its impact on land-use, environment, and ecosystem services. Landscape ecology-The influences of land use and anthropogenic impacts of landscape creation, 1-26.

Karlberg, L., Hoff, H., Amsalu, T., Andersson, K., Binnington, T., Flores-López, F., de Bruin, A., Gebrehiwot, S.G., Gedif, B., Johnson, O. (2015) Tackling complexity: understanding the food-energy-environment nexus in Ethiopia's Lake tana subbasin. Water Alternatives 8.

Ketema, H., Wei, W., Legesse, A., Wolde, Z., Temesgen, H., Yimer, F., Mamo, A. (2020) Quantifying smallholder farmers' managed land use/land cover dynamics and its drivers in contrasting agro-ecological zones of the East African Rift. Global Ecology and Conservation 21, e00898.

Kurian, M. (2017) The water-energy-food nexus: trade-offs, thresholds and transdisciplinary approaches to sustainable development. Environmental Science \& Policy 68, 97-106.

Laspidou, C.S., Mellios, N., Kofinas, D. (2019) Towards Ranking the Water-EnergyFood-Land Use-Climate Nexus Interlinkages for Building a Nexus Conceptual Model with a Heuristic Algorithm. Water 11, 306.

Lawford, R.G. (2019) A design for a data and information service to address the knowledge needs of the Water-Energy-Food (WEF) Nexus and strategies to facilitate its implementation. Frontiers in Environmental Science 7, 56.

Lee, S.-H., Mohtar, R.H., Yoo, S.-H. (2019) Assessment of food trade impacts on water, food, and land security in the MENA region. Hydrology and Earth System Sciences 23, 557-572.

Li, H., Zhao, Y., Lin, J. (2020) A review of the energy-carbon-water nexus: Concepts, research focuses, mechanisms, and methodologies. Wiley Interdisciplinary Reviews: Energy and Environment 9, e358. 
132 Li, P.-C., Ma, H.-W. (2020) Evaluating the environmental impacts of the water-energy133 food nexus with a life-cycle approach. Resources, Conservation and Recycling 157, 134104789.

135 Liu, J., Yang, H., Cudennec, C., Gain, A.K., Hoff, H., Lawford, R., Qi, J., Strasser, L.d., 136 Yillia, P., Zheng, C. (2017) Challenges in operationalizing the water-energy-food 137 nexus. Hydrological Sciences Journal 62, 1714-1720.

138 Liu, Q. (2016) Interlinking climate change with water-energy-food nexus and related 139 ecosystem processes in California case studies. Ecological Processes 5, 14.

140 Mabhaudhi, T., Nhamo, L., Mpandeli, S., Nhemachena, C., Senzanje, A., Sobratee, 141 N., Chivenge, P.P., Slotow, R., Naidoo, D., Liphadzi, S. (2019) The Water-Energy-Food 142 Nexus as a Tool to Transform Rural Livelihoods and Well-Being in Southern Africa. 143 International journal of environmental research and public health 16, 2970.

144 Maydeu-Olivares, A., Shi, D., Rosseel, Y. (2019) Instrumental variables two-stage least 145 squares (2SLS) vs. maximum likelihood structural equation modeling of causal effects 146 in linear regression models. Structural Equation Modeling: A Multidisciplinary Journal $147 \quad 26,876-892$.

148 Mendoza, L.C., Cruz, G.A., Ciencia, A.N., Penalba, M.A. (2020) Local Policy and 149 Water Access in Baguio City, Philippines. International Journal of Social Ecology and 150 Sustainable Development (IJSESD) 11, 1-13.

151 Mohamed, A.A. (2017) Food security situation in Ethiopia: a review study. 152 International Journal of Health Economics and Policy 2, 86-96.

153 MOHAMMED, A., (2016) PROBLEMS AND PROSPECTS OF RURAL SAVING AND CREDIT 154 COOPERATIVES (RUSACCOS) IN THE CONTEXT OF CHRONICALLY FOOD INSECURE 155 AREAS: THE CASE OF MESKAN DISTRICT, GURAGE ZONE, SOUTHERN NATIONS, 156 NATIONALITIES AND PEOPLE REGION (SNNPR). St. Mary's University.

157 Mohtar, R.H., Lawford, R. (2016) Present and future of the water-energy-food nexus 158 and the role of the community of practice. Journal of Environmental Studies and 159 Sciences 6, 192-199.

160 Nie, Y., Avraamidou, S., Xiao, X., Pistikopoulos, E.N., Li, J., Zeng, Y., Song, F., Yu, J., Zhu, 161 M. (2019) A Food-Energy-Water Nexus approach for land use optimization. Science 162 of The Total Environment 659, 7-19.

163 Nyberg-Sørensen, N., Hear, N.V., Engberg-Pedersen, P. (2002) The migration164 development nexus: evidence and policy options. International Migration 40, 49-73. 165 Orr, S., Pittock, J., Chapagain, A., Dumaresq, D. (2012) Dams on the Mekong River: 166 Lost fish protein and the implications for land and water resources. Global 167 Environmental Change 22, 925-932.

168 Pahl-Wostl, C. (2019) Governance of the water-energy-food security nexus: A multi169 level coordination challenge. Environmental Science \& Policy 92, 356-367.

170 Pimentel, D., Whitecraft, M., Scott, Z.R., Zhao, L., Satkiewicz, P., Scott, T.J., Phillips, J., 171 Szimak, D., Singh, G., Gonzalez, D.O. (2010) Will limited land, water, and energy 172 control human population numbers in the future? Human Ecology 38, 599-611. 
173 Rasul, G. (2016) Managing the food, water, and energy nexus for achieving the 174 Sustainable Development Goals in South Asia. Environmental Development 18, 1425.

Rijal, S., Rimal, B., Stork, N., Sharma, H.P. (2020) Quantifying the drivers of urban expansion in Nepal. Environmental Monitoring and Assessment 192, 1-17. Ringler, C., Bhaduri, A., Lawford, R. (2013) The nexus across water, energy, land and food (WELF): potential for improved resource use efficiency? Current Opinion in Environmental Sustainability 5, 617-624. Saaty, T.L., (2016) The analytic hierarchy and analytic network processes for the measurement of intangible criteria and for decision-making, Multiple criteria decision analysis. Springer, pp. 363-419. Shieh, G. (2010) On the misconception of multicollinearity in detection of moderating effects: Multicollinearity is not always detrimental. Multivariate Behavioral Research 45, 483-507. Sola, P., Cerutti, P.O., Zhou, W., Gautier, D., liyama, M., Schure, J., Chenevoy, A., Yila, J., Dufe, V., Nasi, R. (2017) The environmental, socioeconomic, and health impacts of woodfuel value chains in Sub-Saharan Africa: a systematic map. Environmental Evidence 6, 4. Spiegelberg, M., Baltazar, D.E., Sarigumba, M.P.E., Orencio, P.M., Hoshino, S., Hashimoto, S., Taniguchi, M., Endo, A. (2017) Unfolding livelihood aspects of the water-energy-food nexus in the dampalit watershed, Philippines. Journal of Hydrology: Regional Studies 11, 53-68. Sušnik, J., Chew, C., Domingo, X., Mereu, S., Trabucco, A., Evans, B., VamvakeridouLyroudia, L., Savić, D., Laspidou, C., Brouwer, F. (2018) Multi-stakeholder development of a serious game to explore the water-energy-food-land-climate nexUs: The SIM4NEXUS approach. Water 10, 139.

199 Taherzadeh, O., Caro, D. (2019) Drivers of water and land use embodied in 200 international soybean trade. Journal of cleaner production 223, 83-93.

201 Tanner, A.M., Johnston, A.L. (2017) The impact of rural electric access on 202 deforestation rates. World Development 94, 174-185.

203 Terrapon-Pfaff, J., Ortiz, W., Dienst, C., Gröne, M.-C. (2018) Energising the WEF nexus 204 to enhance sustainable development at local level. Journal of environmental 205 management 223, 409-416.

206 Thanh, L.N., De Smedt, F. (2012) Application of an analytical hierarchical process 207 approach for landslide susceptibility mapping in A Luoi district, Thua Thien Hue 208 Province, Vietnam. Environmental Earth Sciences 66, 1739-1752.

209 Trock, W.L. (1969) Institutional Factors Affecting Land and Water Development, 210 Lower Rio Grande Valley, Texas. Water Resources Research 5, 1364-1366.

211 van Gevelt, T. (2020) The water-energy-food nexus: bridging the science-policy 212 divide. Current Opinion in Environmental Science \& Health 13, 6-10.

213 Vivoda, V., (2017) Energy security issues in Asia, Routledge Handbook of Energy in 214 Asia. Routledge, pp. 272-283. 
215 Wang, Y., Zhao, T. (2018) Impacts of urbanization-related factors on CO2 emissions: 216 evidence from China's three regions with varied urbanization levels. Atmospheric 217 Pollution Research 9, 15-26.

218 Weitz, N., Nilsson, M., Davis, M. (2014) A nexus approach to the post-2015 agenda: 219 Formulating integrated water, energy, and food SDGs. SAIS Review of International 220 Affairs 34, 37-50.

221 Wiegleb, V., Bruns, A. (2018) What is driving the water-energy-food nexus? 222 Discourses, knowledge, and politics of an emerging resource governance concept. 223 Frontiers in Environmental Science 6, 128.

224 Wolde, Z., Wei, W., Kunpeng, W., Ketema, H. (2020) Local community perceptions 225 toward livelihood and water-energy-food nexus: A perspective on food security. 226 Food and Energy Security, e207.

227 Zare, M., Mohammadi-Ivatloo, B., Abapour, M., Asadi, S., Mohammadi, G., (2020) 228 The Necessity of a Food-Energy-Water Nexus Approach for Lake Urmia Basin Under 229 the Risks of Climate Change and Environment Degradation, Food-Energy-Water 230 Nexus Resilience and Sustainable Development. Springer, pp. 201-227. 
Figures

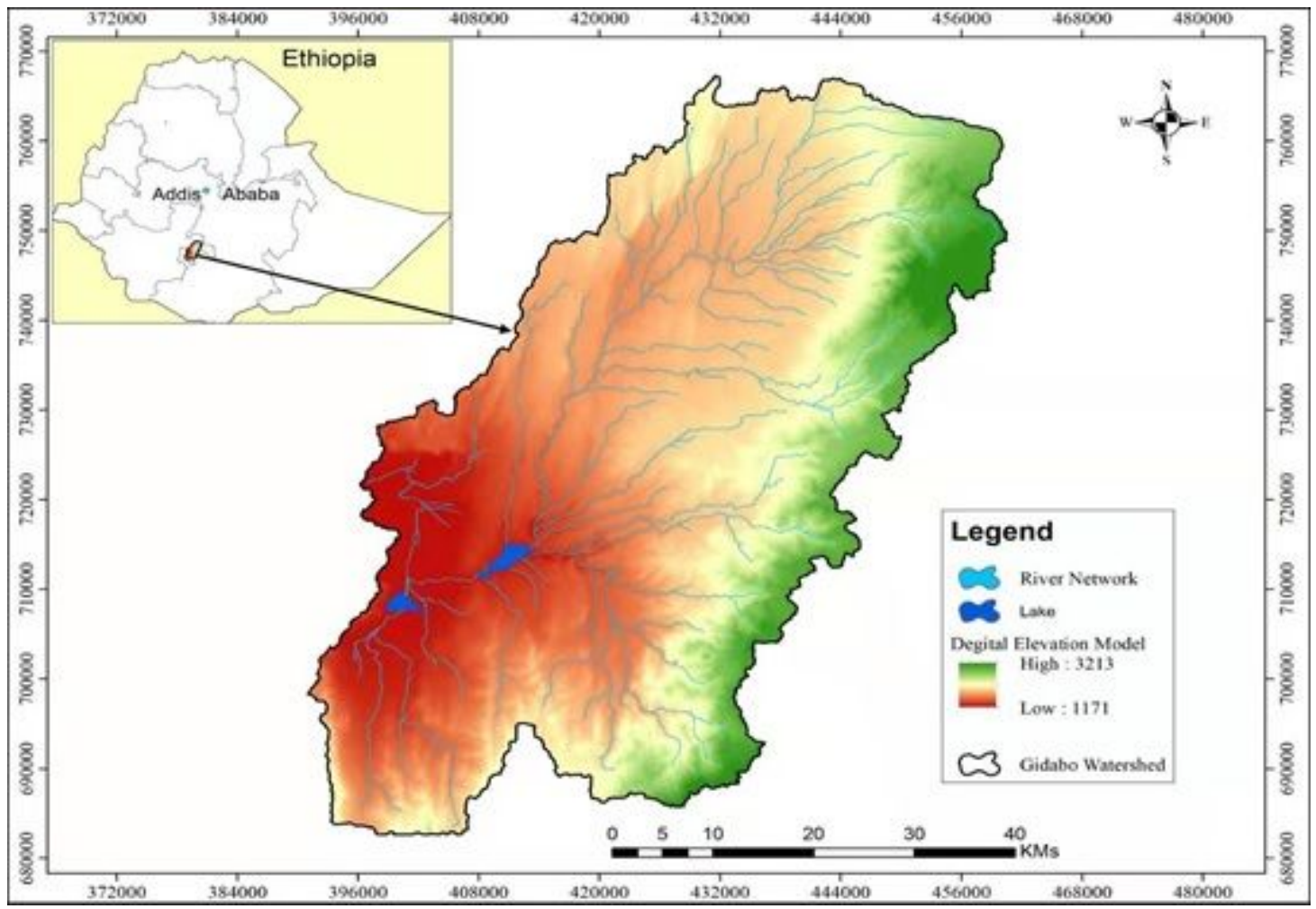

Figure 1

Map of the case study area.

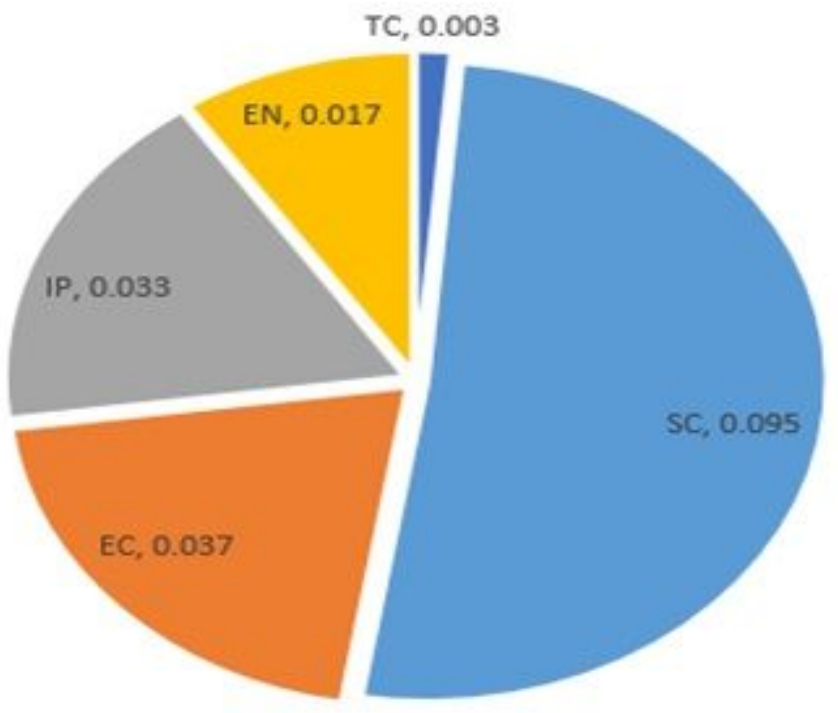

Figure 2

The weight of five main nexus resources driving factor indicators $(E C=$ economic, IP= institutional and policy change, $\mathrm{SC}=$ social, $\mathrm{EN}=$ environmental and $\mathrm{TC}=$ technological drivers) 


\section{LWEF nexus driving factors}

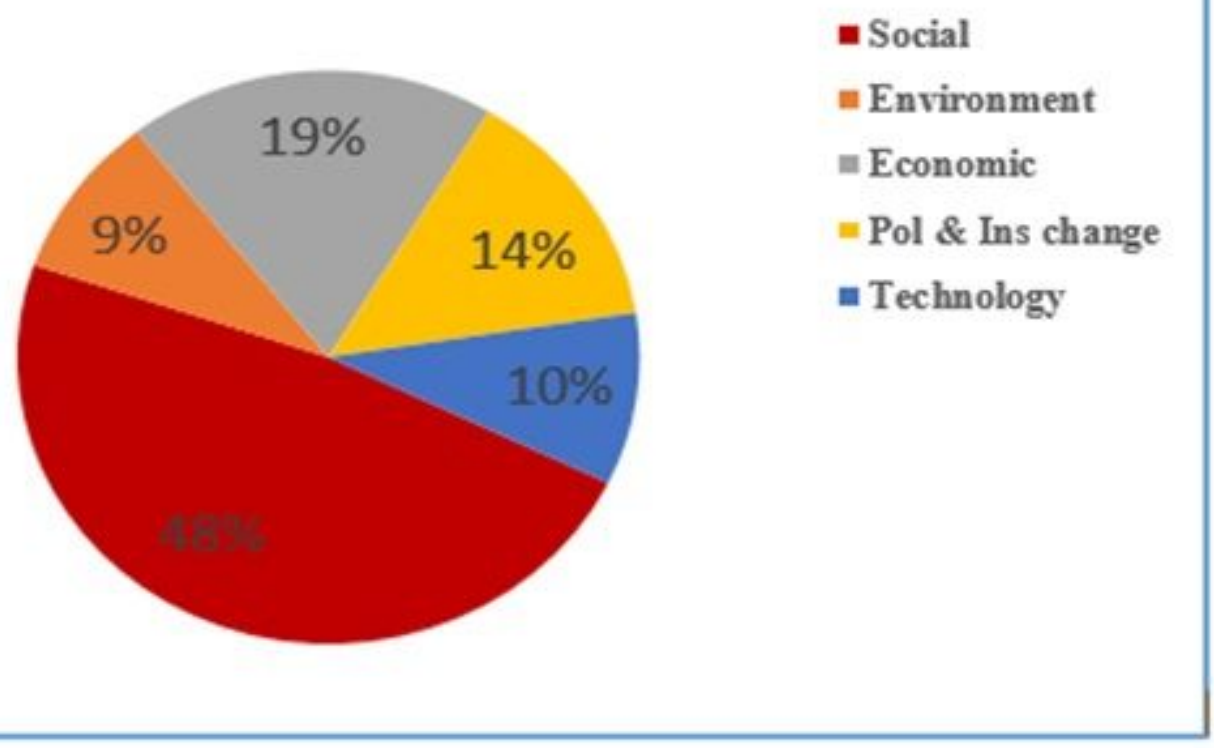

Figure 3

Main LWEF nexus resources driving indicator (Pol \& Ins change= policy and institutional change).

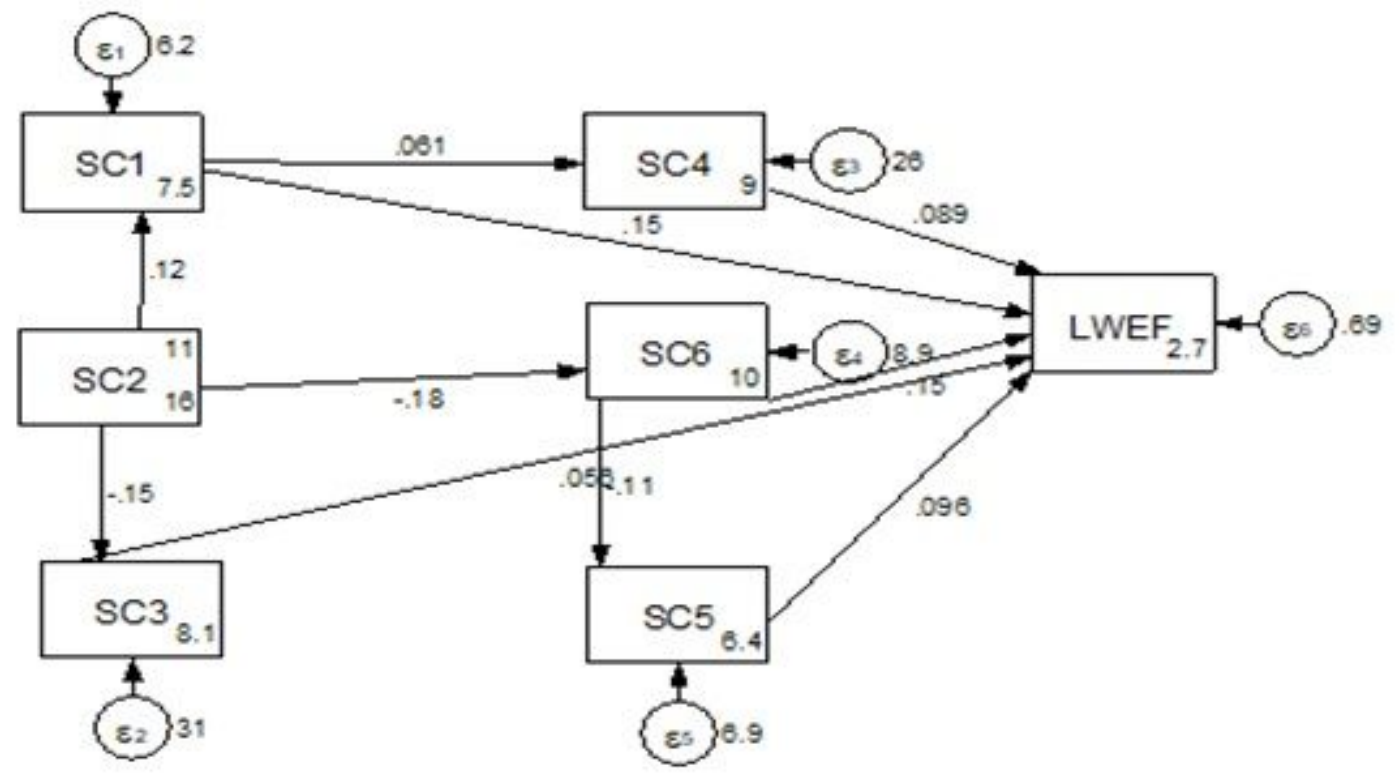

Figure 4

The social driving factor indicator (SC1= population growth, SC2=poverty, SC3= lack of alternative livelihoods, SC4= consumption patterns, SC5= community awareness, and SC6= lack of public involvement) 


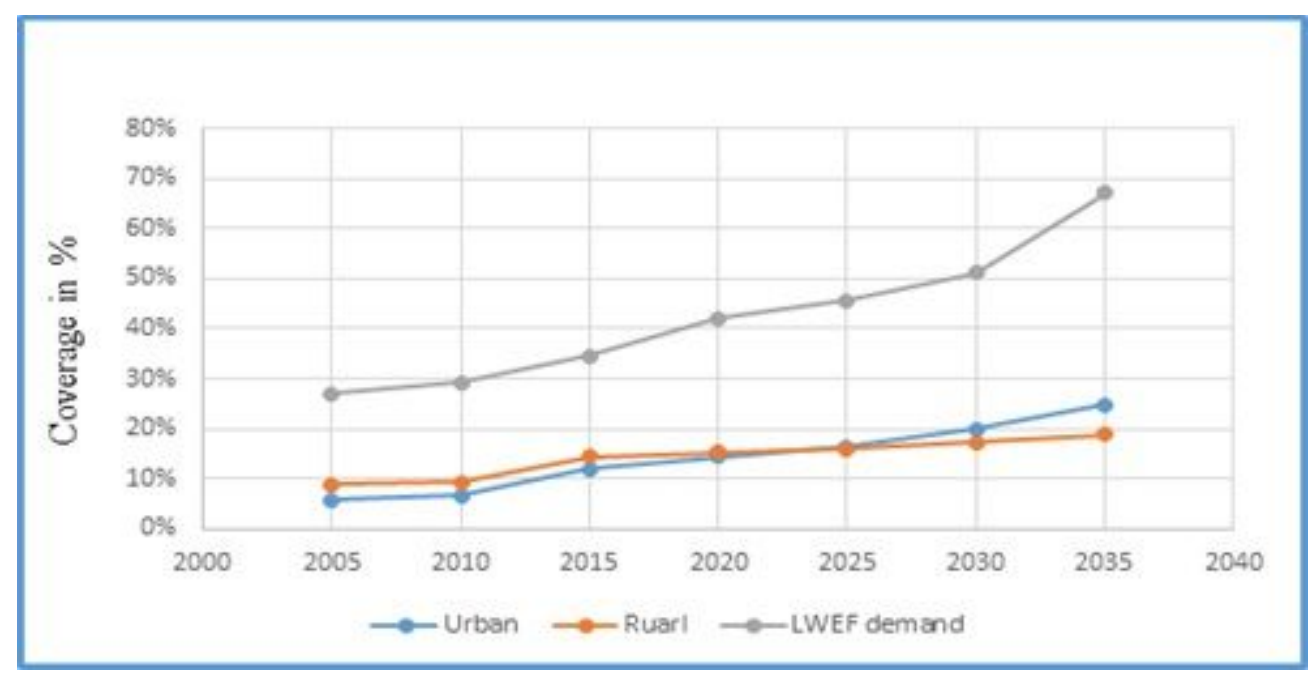

\section{Figure 5}

Population projection in the study area (data source: Central Rift Valley document)

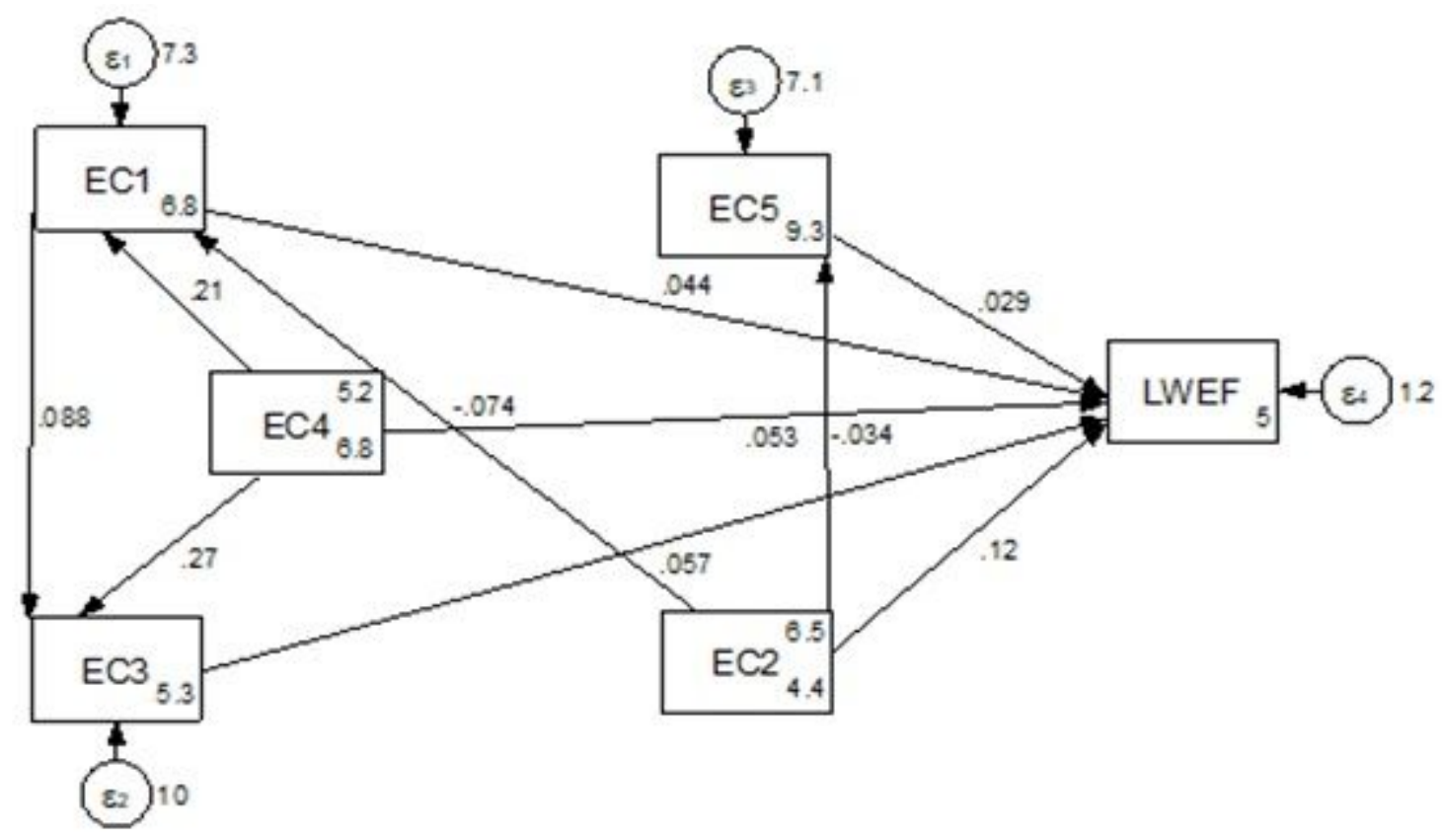

\section{Figure 6}

Economic driver indicator of LWEF nexus resources $(E C 1=$ increasing income variability, EC2= local capital, EC3= increasing WEF prices, EC4= increasing land value, and EC5= inadequate financial resources) 


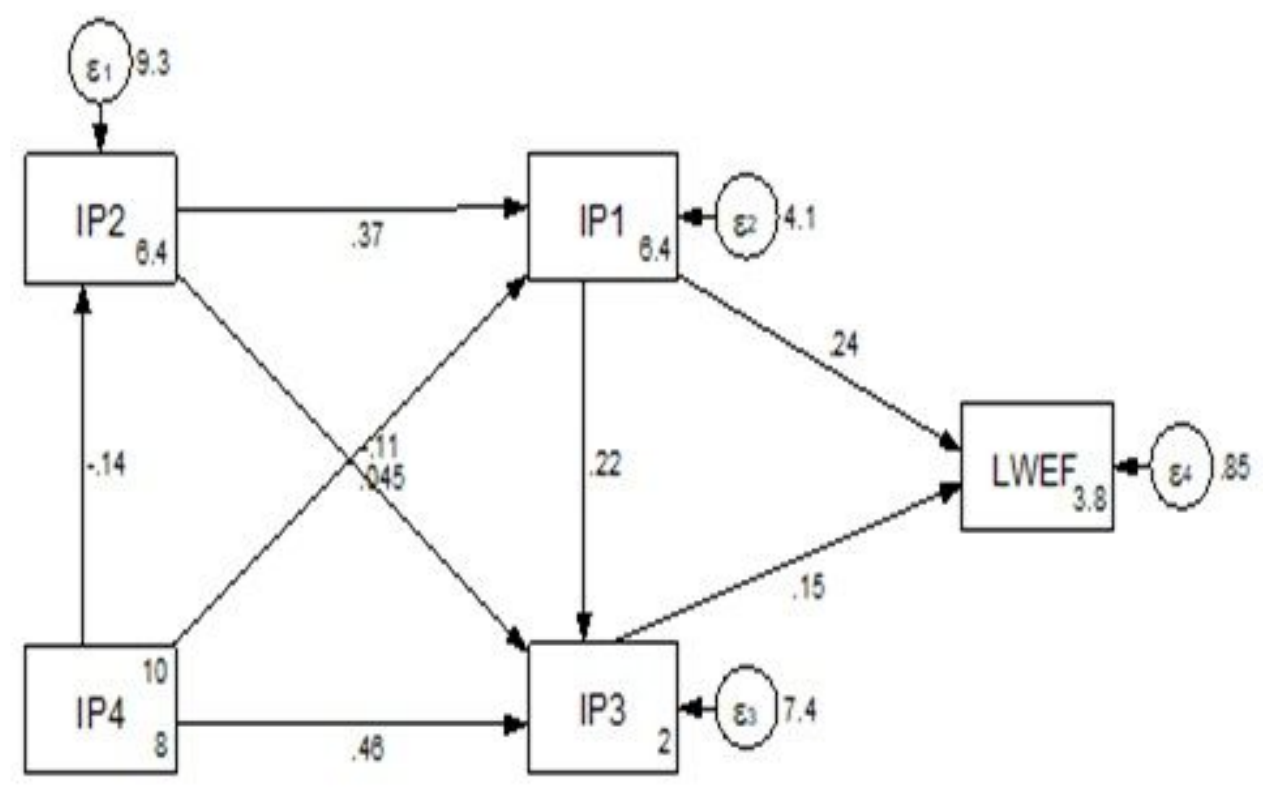

Figure 7

The direct and indirect impact of institutional and policy change driver on LWEF nexus (Outdated legislation (IP1), inadequate financial capital (IP2), poor institutional structure (IP3) and poor stakeholder network (IP4))

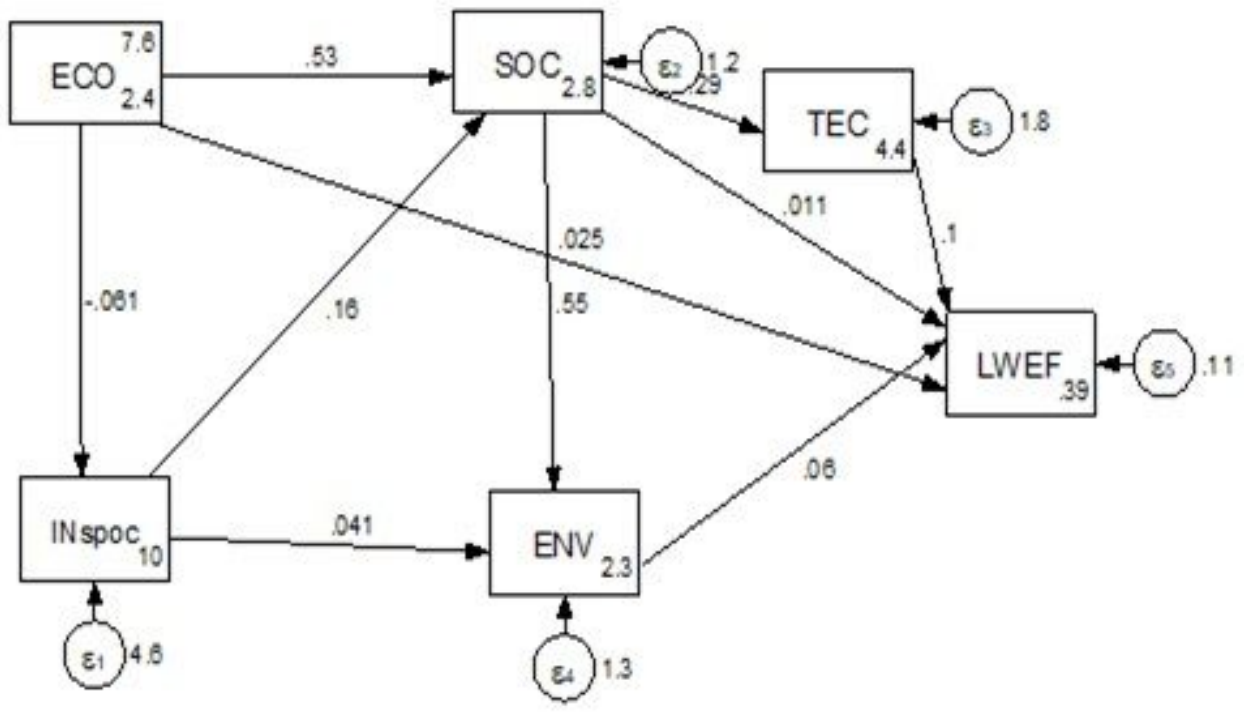

Figure 8

The final comprehensive path model which tested how main driving factor indicator affect LWEF nexus. The indices of model fit demonstrated excellent goodness-of-fit $\left(X_{-}((6))^{\wedge} 2=7.24, p=0.31, T L I=0.99\right.$; $\mathrm{NFI}=0.92 ; \mathrm{RMSEA}=0.03)$ and all paths in the model are significant at $p<0.05$ 


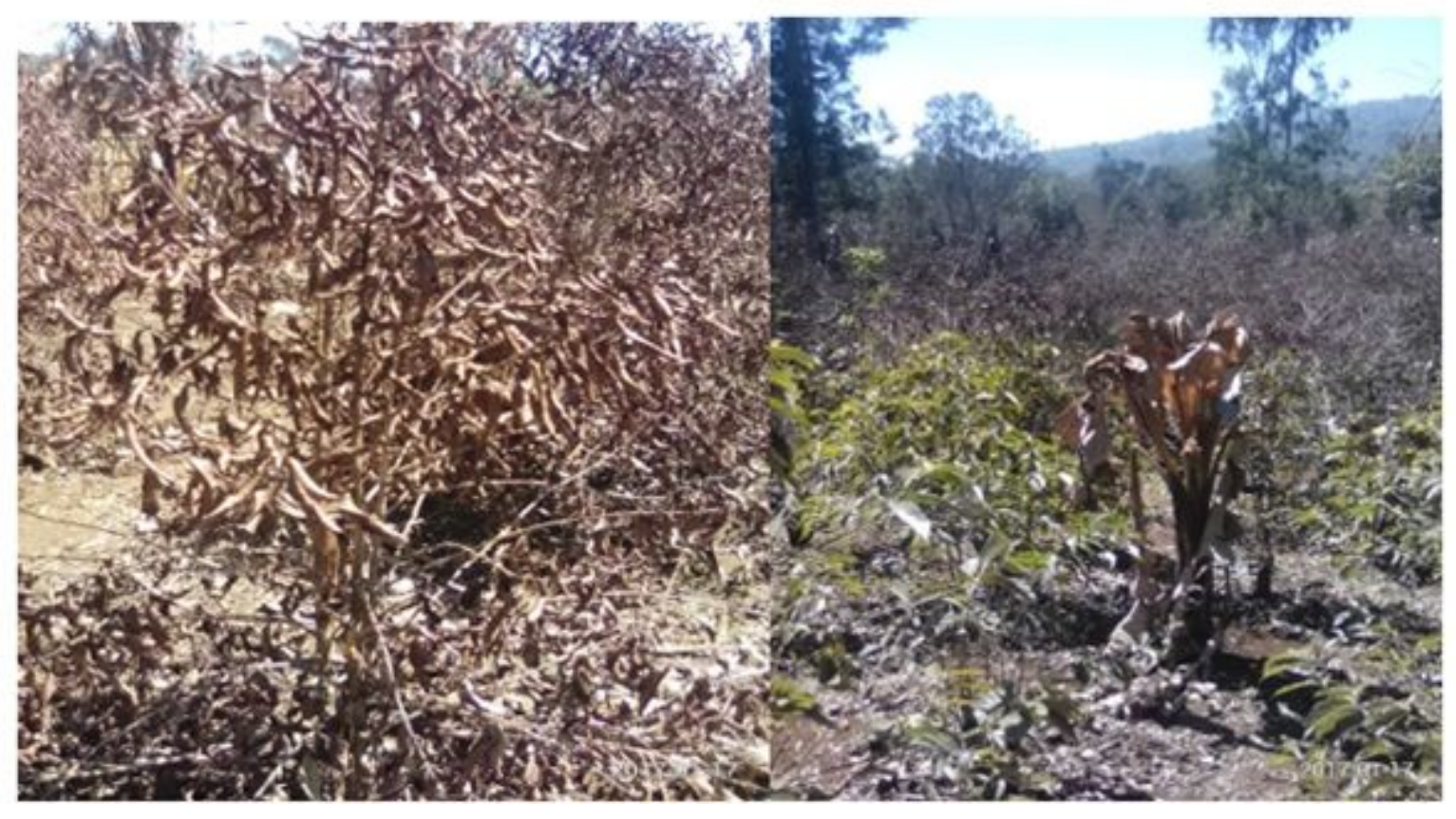

\section{Figure 9}

The impact of frost due to climatic variability in the highland part of Gidabo watershed

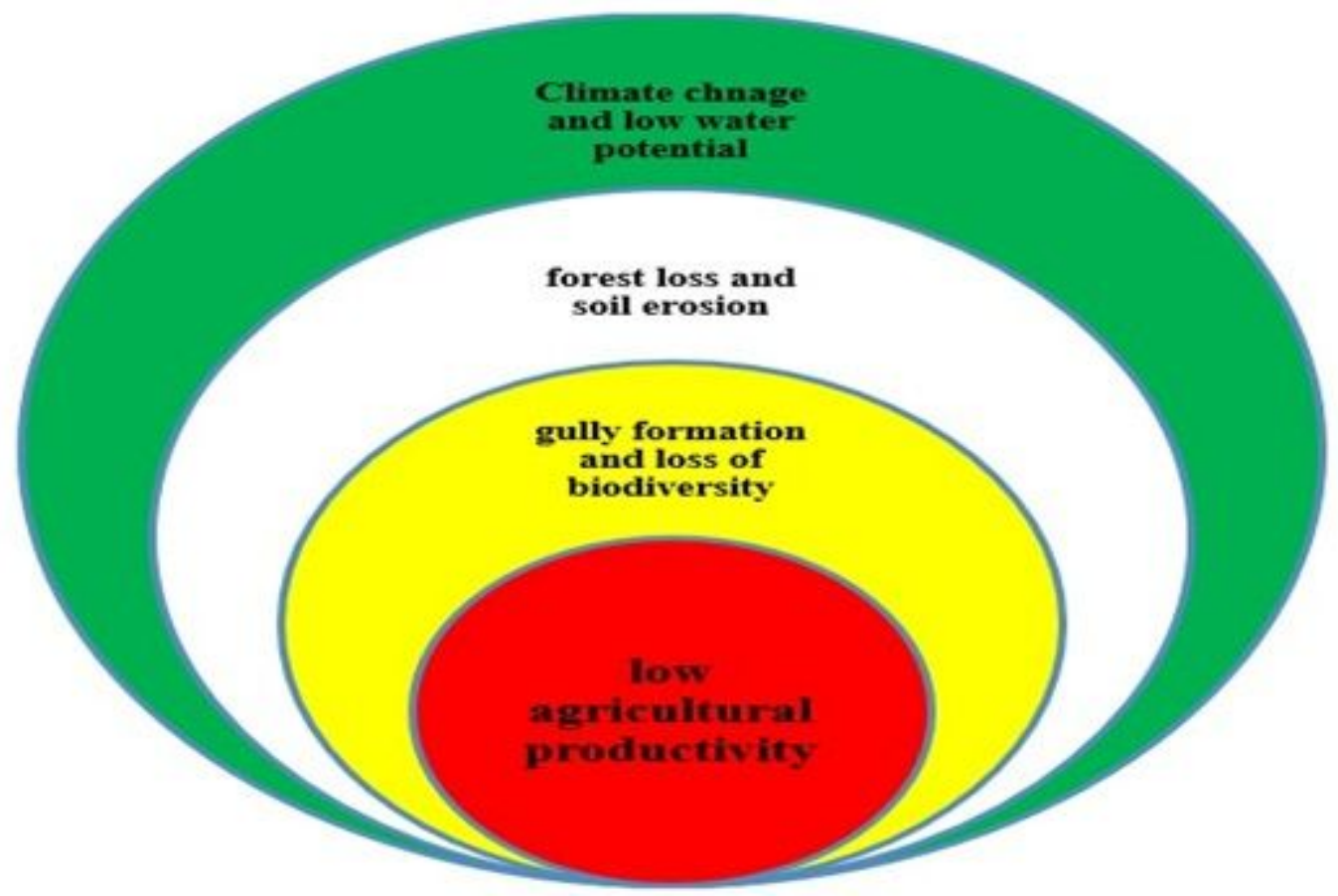

Figure 10

LWEF nexus resources degradation impact on ecological characteristics 